\title{
Papers
}

\section{$\beta$ lactam monotherapy versus $\beta$ lactam-aminoglycoside combination therapy for sepsis in immunocompetent patients: systematic review and meta-analysis of randomised trials}

\author{
Mical Paul, Ishay Benuri-Silbiger, Karla Soares-Weiser, Leonard Leibovici
}

\begin{abstract}
Objective To compare $\beta$ lactam monotherapy with $\beta$ lactam-aminoglycoside combination therapy for severe infections.

Data sources Medline, Embase, Lilacs, Cochrane Library, and conference proceedings, to 2003; references of included studies; contact with all authors. No restrictions, such as language, year of publication, or publication status.

Study selection All randomised trials of $\beta$ lactam monotherapy compared with $\beta$ lactam-aminoglycoside combination therapy for patients without neutropenia who fulfilled criteria for sepsis. Data selection Two reviewers independently applied selection criteria, performed quality assessment, and extracted the data. The primary outcome assessed was all cause fatality by intention to treat. Relative risks were pooled with the random effect model (relative risk $<1$ favours monotherapy). Results 64 trials with 7586 patients were included. There was no difference in all cause fatality (relative risk $0.90,95 \%$ confidence interval 0.77 to 1.06 ). 12 studies compared the same $\beta$ lactam (1.02, 0.76 to 1.38), and 31 studies compared different $\beta$ lactams $(0.85,0.69$ to 1.05$)$. Clinical failure was more common with combination treatment overall $(0.87,0.78$ to 0.97$)$ and among studies comparing different $\beta$ lactams $(0.76,0.68$ to 0.86). There was no advantage to combination therapy among patients with Gram negative infections (1835 patients) or Pseudomonas aeruginosa infections (426 patients). There was no difference in the rate of development of resistance.

Nephrotoxicity was significantly more common with combination therapy $(0.36,0.28$ to 0.47$)$. Heterogeneity was not significant for these comparisons.

Conclusions In the treatment of sepsis the addition of an aminoglycoside to $\beta$ lactams should be discouraged. Fatality remains unchanged, while the risk for adverse events is increased.
\end{abstract}

\section{Introduction}

Treatment with a combination of $\beta$ lactam and an aminoglycoside is purported to be superior to $\beta$ lactam monotherapy for sepsis on the basis of potential advantages such as in vitro synergism and prevention of development of resistance. ${ }^{1-7}$ Textbooks and guidelines advise the combination for specific pathogens, such as Pseudomonas aeruginosa and other Gram negative bacteria, and for infections commonly caused by these pathogens. ${ }^{8}{ }^{9} \mathrm{In}$ aiming for optimal antibiotic treatment of severe infections, hospital clinicians tend to use combination therapy despite the lack of direct evidence for its effectiveness. Observational studies show that $25-30 \%$ of patients with bacteraemia, ${ }^{10}{ }^{11}$ surgical infections, ${ }^{12}$ or pneumonia, ${ }^{13}{ }^{14} 50 \%$ of those with klebsiella bacteraemia, ${ }^{15}$ and $56 \%$ of patients with septic shock in the intensive care unit $^{16}$ are given $\beta$ lactam-aminoglycoside combination therapy.

We performed a systematic review and meta-analysis of randomised trials comparing $\beta$ lactam-aminoglycoside combination therapy with $\beta$ lactam monotherapy for severe infections in patients without neutropenia.

\section{Methods}

We searched Medline, Embase, Lilacs, the Cochrane Library (all up to March 2003), conference proceedings of the Interscience Conference on Antimicrobial Agents and Chemotherapy (19952002), and citations of included trials with the terms: (aminoglycoside* OR specific aminoglycosides) AND ((infect* OR sepsis OR bacter* OR septicemia OR specific infections/pathogens) OR combi*)). We included studies regardless of date, language, or publication status, and we contacted authors for complementary information.

We included all randomised and quasi-randomised trials that compared any $\beta$ lactam monotherapy with any combination of a $\beta$ lactam and an aminoglycoside for severe infections. Severe infection was defined as clinical evidence of infection, plus evidence of a systemic response to infection. ${ }^{17}$ We excluded studies with a dropout rate above $30 \%$, unless intention to treat analysis was given for mortality or failure outcomes, and studies with more than $15 \%$ of patients with neutropenia, neonates, and preterm babies.

The primary outcome assessed was all cause fatality by the end of study follow up and up to 30 days. Secondary outcomes included treatment failure, defined as death, non-resolving primary infection, any modification to allocated antibiotics, or any therapeutic invasive intervention not defined by protocol; bacteriological failure, defined as persistence of primary pathogen; bacterial and fungal superinfections and colonisation; adverse events; and length of hospital stay. We separated studies that compared the same $\beta$ lactam from studies that compared different $\beta$ lactams. We performed subgroup analyses for $P$ aeruginosa infections, any Gram negative infection, bacteraemia, and specific sources of infection.

A full list of references to excluded studies can be found on bmj.com 
Two reviewers independently applied inclusion and exclusion criteria and extracted the data. We extracted outcomes by intention to treat, unless the reasons for exclusions were not presented. In this case, we used the presented results (per protocol analysis) in the main analysis and compared them with results using all randomised patients and assuming failure for drop outs. Heterogeneity was assessed with a $\chi^{2}$ test and the $I^{2}$ measure. ${ }^{18}$ We expected heterogeneity with respect to outcomes and used the random effects model, comparing it to a fixed effect model. ${ }^{19}$ We calculated relative risks with 95\% confidence intervals and numbers needed to treat. Study quality measures extracted were allocation generation and concealment, blinding, intention to treat or per protocol analysis, designation of drop outs to treatment arms, number of drop outs, follow up and outcome predefinitions, and publication status. ${ }^{20}$ The effect of these measures was examined through sensitivity analysis.

We examined a funnel plot of the log of the relative risk against the weight to estimate potential selection bias (such as publication bias) and to assess whether effect estimates were associated with study size.

\section{Results}

We evaluated 144 eligible randomised trials and included 64 in the review (fig 1). The trials included 7586 patients, nearly all adults, and were performed between the years 1968-2001. The median number of patients per trial was 87 (range 20-580). Trials differed by the population targeted, type of infection, and antibiotics compared (table 1). The major conditions were severe sepsis, pneumonia, or Gram negative infections (41 trials), abdominal infections (11 trials), urinary tract infections (7 trials), and Gram positive infections ( 5 trials). Allocation to antibiotics was empirical in 56 trials. The same $\beta$ lactam was compared in 20 trials, while all other trials compared one $\beta$ lactam to a different, narrower spectrum $\beta$ lactam combined with an aminoglycoside.

All cause fatality -Forty three trials including 5527 patients reported all cause fatality. There was no significant difference between monotherapy and combination therapy when we combined these studies (relative risk $0.90,95 \%$ confidence interval 0.77 to 1.06 , fig 2 ). There was no difference among the 12 studies with 1381 patients that compared the same $\beta$ lactam (1.02, 0.76 to 1.38 ) or among studies that compared different $\beta$ lactams $(0.85,0.69$ to 1.05$)$. The heterogeneity for this comparison was low $\left(I^{2}=7.7 \%\right)$.

Treatment failure-We compared clinical and bacteriological failures in 63 and 43 trials, respectively (figs 3 and 4). For both comparisons, monotherapy was not significantly different from combination therapy among studies that compared the same $\beta$ lactam. Monotherapy was significantly superior to combination therapy among studies that compared different $\beta$ lactams. The overall comparison favoured monotherapy for clinical failure ( $0.87,0.78$ to $0.97 ; 6616$ patients; number needed to treat 34,20 to 147$)$ and for bacteriological failure $(0.86,0.72$ to $1.02 ; 3511$ patients).

Subgroup analysis-Major effectiveness outcomes were compared within the defined patient subgroups expected to benefit most from combination therapy (tables 2 and 3). We did not detect an advantage to combination therapy with any subgroup tested. Mortality was higher among patients with $P$ aeruginosa $(21 \%)$, Gram negative infections $(13 \%)$, and bacteraemia (15\%), and outcomes were similar with combination versus monotherapy. Patients with infections outside the urinary tract (mainly pneumonia) had significantly fewer failures with monotherapy. Five trials specifically assessed Gram positive infections,

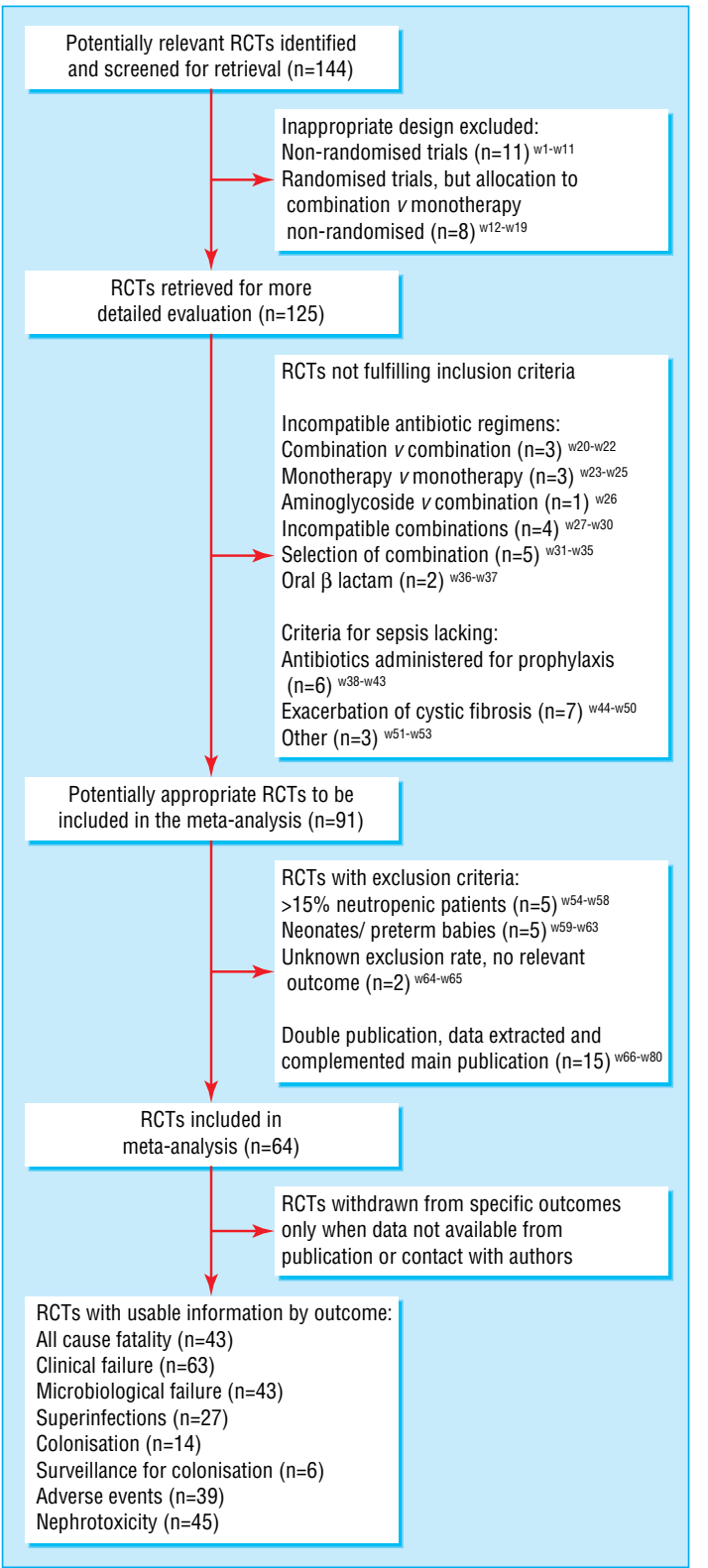

Fig 1 Detail of trial selection. The list of excluded references (w1-w80) can be found on bmj.com

endocarditis in four (table 1). ${ }^{21} 32486369$ Combined relative risks for fatality and failure favoured monotherapy, although differences were non-significant.

Development of resistance-Combination therapy did not lower bacterial superinfection or colonisation rates, which we would have expected if combination therapy prevented the development of resistance (fig 5). Relative risks tended in favour of monotherapy for bacterial superinfections $(0.79,0.59$ to 1.06$)$. Rates of fungal superinfection were similar. Six studies performed routine surveillance cultures, and nine assessed the development of resistance among pretreatment isolates. In these also we found no advantage with combination therapy. Twenty six studies reported coverage rates of the allocated treatment, although outcomes were not related to coverage. Among studies with different $\beta$ lactams, the monotherapy $\beta$ lactam provided broader coverage than the combination $\beta$ lactam in 13 studies, the opposite occurring in two studies. Combined coverage of the 
Table 1 Characteristics of included studies: patients and intervention

\begin{tabular}{|c|c|c|c|c|}
\hline Study & No of patients & Age $(\text { years })^{*}$ & Participants/infection & Intervention \\
\hline Abrams $^{21} 1979$ & 24 & Median 27.5 & $\begin{array}{l}\text { IV drug users with Staphylococcus aureus } \\
\text { endocarditis }\end{array}$ & $\begin{array}{l}\text { Oxacillin }(4 \text { weeks) } v \text { oxacillin }(4 \text { weeks })+ \\
\text { gentamicin }(2 \text { weeks) }\end{array}$ \\
\hline Aguilar $^{22} 1992$ & 36 & 40 (range 16-70) & Severe infections & Ceftizoxime $v$ penicillin + gentamicin \\
\hline Alvarez Lerma ${ }^{23} 2001$ & 140 & $62(14.5)$ & $\begin{array}{l}\text { Mechanically ventilated adults in intensive care unit } \\
\text { with hospital acquired pneumonia. Inotropic support } \\
\text { in } 66 \%\end{array}$ & Meropenem $v$ ceftazidime + amikacin \\
\hline Arich $^{24} 1987$ & 47 & $68(17)$ & Enterobacteriaceae bacteraemia & Cefotaxime $v$ cefazolin + tobramycin \\
\hline Bergeron $^{25} 1988$ & 77 & 63.5 & Severe biliary infections & Cefoperazone $v$ ampicillin + tobramycin \\
\hline Biglino $^{26} 1991$ & 22 & $47(8.5)$ & $\begin{array}{l}\text { Severe sepsis in immune deficient patients }(73 \%) \\
\text { without neutropenia }\end{array}$ & Imipenem $v$ imipenem + netilmicin \\
\hline Brown $^{27} 1984$ & 34 & $60(17)$ & $\begin{array}{l}\text { Hospital acquired Gram negative pneumonia, } 85 \% \text { of } \\
\text { patients in intensive care unit }\end{array}$ & Moxalactam $v$ carbenicillin + tobramycin \\
\hline Carbon $^{28} 1987$ & 74 & $70(15)$ & $\begin{array}{l}\text { Enterobacteriaceae bacteraemia; } 15 \% \text { patients with } \\
\text { septic shock }\end{array}$ & Cefotaxime $v$ cefotaxime + amikacin \\
\hline Cardozo $^{29} 2001$ & 110 & $7.7(0.7)$ & Acute appendicitis & $\begin{array}{l}\text { Amoxicillin-sulbactam } v \text { amoxicillin } \\
\text {-sulbactam }+ \text { gentamicin once daily }\end{array}$ \\
\hline $\begin{array}{l}\text { Cometta }^{30} \\
1994\end{array}$ & 313 & $56(18)$ & $\begin{array}{l}\text { Hospital acquired pneumonia, sepsis, or severe } \\
\text { diffuse peritonitis; } 73 \% \text { of patients in intensive care } \\
\text { unit, mechanically ventilated in } 48 \%\end{array}$ & Imipenem $v$ imipenem + netilmicin \\
\hline Cone $^{31} 1985$ & 57 & 65 & Pneumonia or bacteraemia & Ceftazidime $v$ ticarcillin + tobramycin \\
\hline Coppens $^{32} 1983$ & 66 & No data & Staphylococcal infections & Cefamandole $v$ cefamandole + tobramycin \\
\hline D’Antonio ${ }^{33} 1992$ & 300 & Median 37 & $\begin{array}{l}\text { Fever in immune deficient patients without } \\
\text { neutropenia }\end{array}$ & Ceftriaxone $v$ ceftriaxone + amikacin \\
\hline Duff $^{34} 1982$ & 74 & Adults & $\begin{array}{l}\text { Endomyoparametritis after delivery or pelvic cellulitis } \\
\text { after hysterectomy }\end{array}$ & Cefoxitin $v$ penicillin + gentamicin \\
\hline Dupont $^{35} 2000$ & 227 & $61.5(18)$ & $\begin{array}{l}\text { Severe generalised peritonitis with surgically proved } \\
\text { intra-abdominal infections }\end{array}$ & $\begin{array}{l}\text { Piperacillin-tazobactam } v \\
\text { piperacillin-tazobactam }+ \text { amikacin }\end{array}$ \\
\hline Felisart $^{36} 1985$ & 73 & $55(10)$ & $\begin{array}{l}\text { Patients with advanced cirrhosis and } \\
\text { severe infections, mostly spontaneous bacterial } \\
\text { peritonitis }\end{array}$ & Cefotaxime $v$ ampicillin + tobramycin \\
\hline Finer $^{37} 1992$ & 471 & $61(18)$ & $\begin{array}{l}\text { Serious bacterial infections; } 5 \% \text { of patients in critical } \\
\text { sepsis }\end{array}$ & $\begin{array}{l}\text { Ceftazidime } v \text { ureidopenillin + aminoglycoside used } \\
\text { routinely }\end{array}$ \\
\hline Gerecht $^{38} 1989$ & 46 & $66(29-92)$ & Cholangitis with positive blood or bile cultures & Mezlocillin $v$ ampicillin + gentamicin \\
\hline Gomez $^{39} 1990$ & 78 & No data & $\begin{array}{l}\text { Gram negative bacteraemia; } 11.5 \% \text { of patients in } \\
\text { critical sepsis }\end{array}$ & Ceftazidime $v$ cefradine + amikacin \\
\hline Havig $^{40} 1973$ & 68 & 65 & Acute cholecystitis & Ampicillin $v$ penicillin + streptomycin (intramuscular) \\
\hline Hoepelman ${ }^{31} 1988$ & 86 & 60 (range 16-90) & Serious bacterial infections & Ceftriaxone $v$ cefuroxime + gentamicin \\
\hline Holloway ${ }^{42} 1985$ & 43 & Adults & Gram negative bacteraemia or pneumonia & Ticarcillin-clavulanate $v$ piperacillin + tobramycin \\
\hline lakovlev"43 1998 & 95 & $41.5(2.5)$ & Severe hospital acquired infections & Meropenem $v$ ceftazidime + amikacin \\
\hline Jaspers ${ }^{44} 1998$ & 79 & 76 (range 65-91) & Sepsis syndrome & Meropenem $v$ cefuroxime + gentamicin once daily \\
\hline Klastersky ${ }^{45} 1973$ & 75 & Adults & $\begin{array}{l}\text { Patients with disseminated cancer and life } \\
\text { threatening infections, presumed Gram negative }\end{array}$ & Carbenicillin $v$ carbenicillin + gentamicin \\
\hline Kljucar $^{46} 1990$ & 100 & $>14$ & $\begin{array}{l}\text { Patients in intensive care unit with hospital acquired } \\
\text { pneumonia, mechanically ventilated }\end{array}$ & Ceftazidime $v$ ceftazidime + tobramycin \\
\hline Koehler $^{47} 1990$ & 144 & 66 (range 18-91) & $\begin{array}{l}\text { Hospital acquired pneumonia; } 5 \% \text { of patients with } \\
\text { critical sepsis }\end{array}$ & Ceftazidime $v$ piperacillin + tobramycin \\
\hline Korzeniowski ${ }^{48} 1982$ & 78 & 38.6 & $\begin{array}{l}\text { Drug addicts and non-addicts with } S \text { aureus } \\
\text { endocarditis }\end{array}$ & $\begin{array}{l}\text { Nafcillin (4 weeks) } v \text { nafcillin }(4 \text { weeks) }+ \text { gentamicin } \\
(2 \text { weeks) }\end{array}$ \\
\hline Landau $^{49} 1990$ & 40 & $75(9)$ & Complicated urinary tract infection & Ceftriaxone $v$ cefazolin + gentamicin \\
\hline Limson $^{50} 1988$ & 40 & $22-78$ & Severe Gram negative infections & Ceftazidime $v$ ticarcillin + amikacin \\
\hline Mandell| 1987 & 110 & 65 (range 17-95) & Pneumonia (mostly hospital acquired) & Ceftazidime $v$ cefazolin or ticarcillin + tobramycin \\
\hline Martin $^{52} 1991$ & 116 & 40 & Pyelonephritis & Ceftriaxone $v$ ampicillin + gentamicin \\
\hline McCormick ${ }^{53} 1997$ & 128 & $51(1.7)$ & Patients with cirrhosis and sepsis & Ceftazidime $v$ mezlocillin + netilmicin \\
\hline Mergoni ${ }^{54} 1987$ & 42 & $52(18)$ & Patients in intensive care unit with severe infections & Azlocillin $v$ azloclillin + amikacin \\
\hline Moreno5 1997 & 70 & 39.6 & $\begin{array}{l}\text { Renal or kidney-pancreas transplant patients with } \\
\text { suspected bacterial infection }\end{array}$ & Imipenem $v$ piperacillin + tobramycin \\
\hline Mouton $^{56} 1990$ & 211 & 58 (range 18-82) & $\begin{array}{l}\text { Patients in intensive care unit with pneumonia or } \\
\text { bacteraemia }\end{array}$ & Imipenem $v$ cefotaxime + amikacin \\
\hline Mouton $^{57} 1995$ & 237 & 61 (range 18-4) & $\begin{array}{l}\text { Community or hospital acquired serious infections, } \\
\text { excluding intra-abdominal sepsis; } 10 \% \text { of patients in } \\
\text { critical sepsis }\end{array}$ & Meropenem $v$ ceftazidime + amikacin \\
\hline Muller $^{58} 1987$ & 106 & 51.5 & Biliary infections & Piperacillin $v$ cefoperazone $v$ ampicillin + tobramycin \\
\hline Naime Libien ${ }^{59} 1992$ & 30 & $2.8(3.3)$ & Severe lower respiratory tract infections & Ceftizoxime $v$ penicillin + gentamicin \\
\hline Piccart $^{60} 1984$ & 105 & Median 63 (range 19-90) & $\begin{array}{l}\text { Cancer patients (only non-neutropenic included in } \\
\text { review) with suspected Gram negative infections. } \\
\text { Gram positive bacteraemia excluded }\end{array}$ & Cefoperazone $v$ cefoperazone + amikacin \\
\hline Rapp $^{61} 1984$ & 35 & Adults & $\begin{array}{l}\text { Patients in neurosurgical intensive care unit with } \\
\text { hospital acquired pneumonia }\end{array}$ & Ceftazidime $v$ ticarcillin + tobramycin \\
\hline Rasmussen $^{62} 1986$ & 59 & $61(4)$ & $\begin{array}{l}\text { Patients in urosurgical department with urinary tract } \\
\text { infections, mostly postoperative }\end{array}$ & Cefotaxime $v$ ampicillin + netilmicin \\
\hline
\end{tabular}




\begin{tabular}{|c|c|c|c|c|}
\hline Study & No of patients & Age (years) ${ }^{*}$ & Participants/infection & Intervention \\
\hline Ribera $^{63} 1996$ & 90 & $26.7(4)$ & $\begin{array}{l}\text { Intravenous drug addicts, } 90.5 \% \text { HIV positive, with } \\
S \text { aureus right sided endocarditis }\end{array}$ & Cloxacillin $v$ cloxacillin + gentamicin \\
\hline Rubinstein $^{64} 1995$ & 580 & 56 & $\begin{array}{l}\text { Hospital acquired bacterial infections: pneumonia, } \\
\text { primary sepsis, or upper urinary tract infections; } \\
9.3 \% \text { with life threatening infections }\end{array}$ & Ceftazidime $v$ ceftriaxone + tobramycin once daily \\
\hline Sage $^{65} 1987$ & 61 & 54 (range 14-85) & $\begin{array}{l}\text { Suspected life threatening sepsis, caused by } \\
\text { enterobacteriaceae or staphylococci }\end{array}$ & Cefotaxime $v$ cefotaxime + netilmicin \\
\hline Sandberg $^{66} 1997$ & 73 & Median 54 (range 18-89) & Women with pyelonephritis & Cefotaxime $v$ cefotaxime + tobramycin once daily \\
\hline Sanfilippo ${ }^{67} 1989$ & 26 & $16-19$ & Acute pelvic inflammatory disease & Mezlocillin $v$ penicillin + tobramycin \\
\hline Sculier $^{68} 1982$ & 20 & $21-78$ & $\begin{array}{l}\text { Patients in neurosurgical intensive care unit with } \\
\text { Gram negative pneumonia, mechanically ventilated }\end{array}$ & Mezlocillin $v$ mezlocillin + sisomicin \\
\hline $\operatorname{Sexton}^{69} 1998$ & 67 & $56(18)$ & $\begin{array}{l}\text { Native valve endocarditis caused by } \\
\text { penicillin-susceptible streptococci }\end{array}$ & $\begin{array}{l}\text { Ceftriaxone ( } 4 \text { weeks) } v \text { ceftriaxone ( } 2 \text { weeks) }+ \\
\text { gentamicin ( } 2 \text { weeks) }\end{array}$ \\
\hline$\overline{\text { Sieger }^{70} 1997}$ & 211 & 54.5 (range 17-87) & $\begin{array}{l}\text { Hospital acquired pneumonia; } 70 \% \text { mechanically } \\
\text { ventilated, } 27 \% \text { with severe pneumonia }\end{array}$ & Meropenem $v$ ceftazidime + tobramycin \\
\hline Smith $^{71} 1984$ & 195 & $58.5(19)$ & Serious infections, $21 \%$ of patients in septic shock & Cefotaxime $v$ nafcillin + tobramycin \\
\hline Speich $^{72} 1998$ & 89 & $64.6(18)$ & Severe pneumonia, community acquired in $89 \%$ & $\begin{array}{l}\text { Piperacillin-tazobactam } v \text { amoxicillin- clavulanic acid } \\
+ \text { gentamicin or netilmicin once daily }\end{array}$ \\
\hline Stille $^{73} 1992$ & 337 & 55 (range 19-93) & $\begin{array}{l}\text { Non-life threatening infections of abdominal, } \\
\text { gynaecological, or respiratory tract origin }\end{array}$ & Imipenem $v$ cefotaxime + gentamicin \\
\hline Sukoh $^{74} 1994$ & 63 & 66 (range 29-91) & $\begin{array}{l}\text { Patients with underlying pulmonary disease and } \\
\text { respiratory tract infections }\end{array}$ & $\begin{array}{l}\text { Cefoperazone/sulbactam } v \text { cefoperazone/sulbactam + } \\
\text { aminoglycoside }\end{array}$ \\
\hline Takamoto $^{75} 1994$ & 171 & 66 (range 17-93) & Respiratory tract infections & Imipenem $v$ imipenem + amikacin \\
\hline Thompson $^{76} 1990$ & 96 & 57 & Acute cholangitis & Piperacillin $v$ ampicillin + tobramycin \\
\hline Thompson $^{77} 1993$ & 120 & 44 & Biliary infections & Cefepime $v$ mezlocillin + gentamicin \\
\hline Trujillo $^{78} 1992$ & 30 & $40(10)$ & $\begin{array}{l}\text { Severe skin and soft tissue or respiratory tract } \\
\text { infections }\end{array}$ & Ceftizoxime $v$ ampicillin + gentamicin \\
\hline Vergnon $^{79} 1985$ & 30 & $61(13)$ & Severe bronchopulmonary infections & Cefoperazone $v$ ampicillin + tobramycin \\
\hline Verzasconi ${ }^{80} 1995$ & 93 & $58(22)$ & $\begin{array}{l}\text { Acute pyelonephritis or complicated urinary tract } \\
\text { infections }\end{array}$ & Amoxicillin-clavulonic acid $v$ amoxicillin + gentamicin \\
\hline Warren $^{81} 1983$ & 123 & Median 45 (range 18-95) & $\begin{array}{l}\text { Life threatening infections caused by Gram negative } \\
\text { bacilli; } 12 \% \text { of patients in septic shock }\end{array}$ & Cefoperazone $v$ cefamandole + tobramycin \\
\hline Wiecek $^{82} 1986$ & 20 & Adults & Pyelonephritis & Ceftazidime $v$ cefotaxime + tobramycin \\
\hline Wing $^{83} 1998$ & 179 & $23(5)$ & $\begin{array}{l}\text { Pregnant women }<24 \text { weeks' gestation with } \\
\text { pyelonephritis }\end{array}$ & Cefazolin $v$ ceftriaxone $v$ ampicillin + gentamicin \\
\hline Yellin ${ }^{84} 1993$ & 112 & 35 (range 20-66) & Cholecystitis proved by surgery & Cefepime $v$ mezlocillin + gentamicin \\
\hline
\end{tabular}

*Mean (SD) unless stated differently.

$\beta$ lactam and the aminoglycoside equalled monotherapy in these studies.

Drop outs and adverse events-The dropout rate was $12.6 \%$ and similar in both study groups (1.01, 0.85 to $1.20,24$ studies, 3631 patients). Few patients (2\%) discontinued treatment because of adverse events with no difference between study groups $(0.89$, 0.52 to $1.52,15$ studies, 3042 patient). Nephrotoxicity was more common with combination therapy in nearly all studies, and the combined relative risk was 0.36 ( 0.28 to 0.47 , fig 6$)$, corresponding to a number needed to harm of 15 (14 to 17) for combination therapy.

Sensitivity analysis-Figure 7 shows sensitivity analyses for measures of study quality. Two studies were quasi-randomised as they used patient identifications numbers for allocation (table 4). ${ }^{34}{ }^{49}$ Concealment of allocation was adequate in 33\% (21/64) of studies, and generation of allocation was adequate in 53\% $(34 / 64)$. Seven studies used some type of blinding, most commonly of outcome assessors only. Extraction of data by intention to treat was possible in $46 \%(20 / 43)$ of studies for fatality and in 21\% (13/63) for failure (table 4). ${ }^{4}$ All sensitivity comparisons were non-significant. Adequate concealment and generation of allocation were associated with relative risks closer to 1 for fatality. The advantage of monotherapy was more significant in trials that used some type of blinding. Smaller trials showed larger effect estimates regarding failure. Analysis per protocol and by the fixed effect model did not affect results. The funnel plot for treatment failure generated a nearly symmetrical "funnel distribution."

\section{Discussion}

\section{Main findings}

In this systematic review of all randomised trials we have shown that $\beta$ lactam-aminoglycoside combination therapy and $\beta$ lactam monotherapy for the treatment of sepsis have similar effects in patients without neutropenia.

Twenty trials compared the same $\beta$ lactam. All cause fatality, the most significant and objective outcome, was not reduced by the addition of aminoglycosides. Clinical and bacteriological failure, which may be prone to bias with non-blinded trials and are of much lesser relevance to patients, were not significantly different. However, rates of adverse event increased with the aminoglycoside. Nephrotoxicity was much more common with combination therapy, while vestibular damage and ototoxicity, other important morbidities associated with aminoglycosides, were not routinely examined.

Forty four trials compared a broad spectrum, usually novel, $\beta$ lactam with a "routine" combination regimen. Rates of appropriate antibiotic treatment with combination therapy and monotherapy were similar when reported. Fatality was not significantly different. Failures were significantly more common with combination therapy. Among all trials, we found no evidence for any potential prevention of infection by resistant isolates with combination therapy.

How should these findings be interpreted?

It can be debated which design appropriately examines the clinical interpretation of synergism, studies comparing same or different $\beta$ lactams. Synergism has been defined as a $2 \log _{10}$ or 


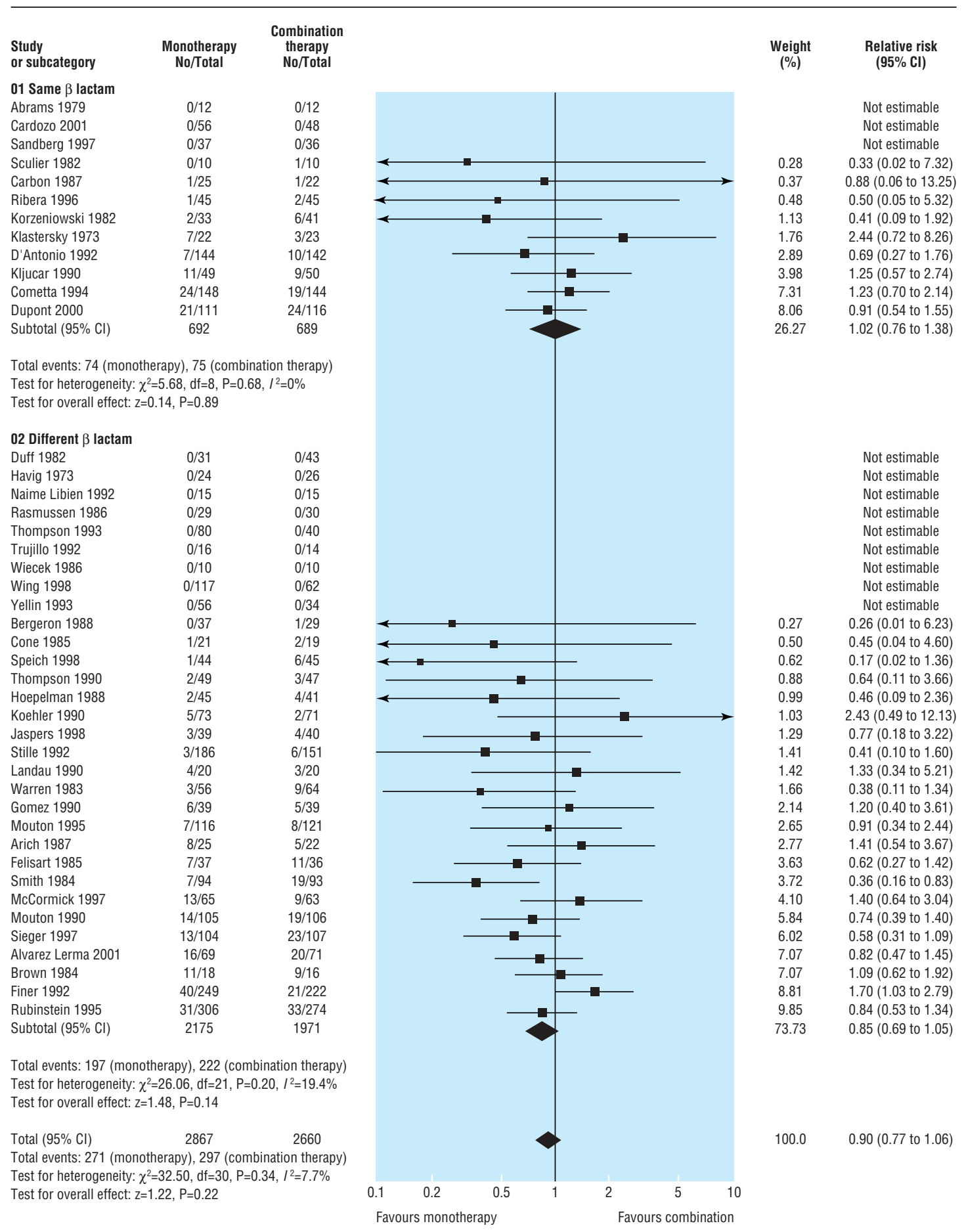

Fig 2 All cause fatality in comparison of $\beta$ lactam monotherapy $v \beta$ lactam-aminoglycoside combination therapy for treatment of sepsis. Log scale of relative risks ( $95 \%$ confidence intervals), random effect model. Studies ordered by weight

greater reduction in bacterial count with the combination versus that with each of the agents alone. ${ }^{86}$ In studies comparing the same $\beta$ lactam this is directly tested, but the effect of increasing the antibiotic spectrum cannot be separated from a synergistic effect. In studies comparing different $\beta$ lactams the spectrum of coverage was similar in both arms. However, synergism can be examined only indirectly. If we assume that the aminoglycoside offers more than its additional coverage, the combination arm should perform as well, or better, than the broader spectrum $\beta$ lactam monotherapy. With the former design we did not detect an advantage to the combination, while with the latter we found an advantage to monotherapy.

\section{Weaknesses of the study}

The quality of included studies was poor overall. We did not detect bias induced by any of the measures assessed. We could not obtain data on all cause fatality for 33\% of studies. It is unlikely that missing results would shift the results for studies 


\begin{tabular}{|c|c|c|c|c|c|c|}
\hline $\begin{array}{l}\text { Study } \\
\text { or subcategory }\end{array}$ & $\begin{array}{l}\text { Monotherapy } \\
\text { No/Total }\end{array}$ & $\begin{array}{c}\text { Combination } \\
\text { therapy } \\
\text { No/Total }\end{array}$ & & & $\begin{array}{c}\text { Weight } \\
(\%)\end{array}$ & $\begin{array}{c}\text { Relative risk } \\
(95 \% \mathrm{Cl})\end{array}$ \\
\hline 01 Same $\beta$ lactam & & & & & & Notestimable \\
\hline $\begin{array}{l}\text { Abrams } 1979 \\
\text { Sexton } 1998\end{array}$ & $\begin{array}{l}0 / 12 \\
1 / 26\end{array}$ & $\begin{array}{l}0 / 12 \\
1 / 25\end{array}$ & & & & $\begin{array}{c}\text { Not estimable } \\
\text { (1) }\end{array}$ \\
\hline Biglino 1991 & $1 / 12$ & $1 / 10$ & $\leftarrow$ & & $\begin{array}{l}0.15 \\
0.16\end{array}$ & $0.83(0.06$ to 11.70 \\
\hline Coppens 1983 & $2 / 22$ & $7 / 44$ & 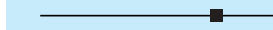 & & 0.50 & 0.57 (0.13 to 2.52$)$ \\
\hline Sage 1987 & $10 / 26$ & $2 / 22$ & & - & 0.55 & $4.23(1.03$ to 17.29$)$ \\
\hline Carbon 1987 & $3 / 25$ & $4 / 22$ & & & 0.57 & 0.66 (0.17 to 2.63$)$ \\
\hline Korzeniowski 1982 & $3 / 33$ & $7 / 41$ & & & 0.67 & $0.53(0.15$ to 1.90$)$ \\
\hline Mergoni 1987 & $4 / 20$ & $4 / 22$ & & a & 0.70 & 1.10 (0.32 to 3.83$)$ \\
\hline Sculier 1982 & $3 / 10$ & $4 / 10$ & & & 0.73 & 0.75 (0.22 to 2.52$)$ \\
\hline Sukoh 1994 & $6 / 30$ & $5 / 33$ & & & 0.92 & $1.32(0.45$ to 3.88$)$ \\
\hline Klastersky 1973 & $11 / 22$ & $4 / 23$ & & $\rightarrow$ & 1.09 & 2.88 (1.07 to 7.69$)$ \\
\hline Piccart 1984 & $7 / 42$ & $11 / 43$ & & & 1.43 & 0.65 (0.28 to 1.52$)$ \\
\hline Cardozo 2001 & $9 / 56$ & $9 / 48$ & $=$ & & 1.45 & 0.86 (0.37 to 1.98$)$ \\
\hline Kljucar 1990 & $12 / 44$ & $9 / 45$ & & $\longrightarrow$ & 1.74 & $1.36(0.64$ to 2.91$)$ \\
\hline Sandberg 1997 & $8 / 26$ & $11 / 35$ & & & 1.75 & 0.98 (0.46 to 2.09 ) \\
\hline Takamoto 1994 & $12 / 77$ & $13 / 80$ & & & 1.91 & 0.96 (0.47 to 1.97$)$ \\
\hline Ribera 1996 & $11 / 45$ & $14 / 45$ & $\longrightarrow$ & - & 2.14 & $0.79(0.40$ to 1.54$)$ \\
\hline Cometta 1994 & $35 / 148$ & $25 / 144$ & & $\longrightarrow$ & 3.93 & 1.36 (0.86 to 2.16$)$ \\
\hline D'Antonio 1992 & $43 / 144$ & $35 / 142$ & & & 5.08 & $1.21(0.83$ to 1.77$)$ \\
\hline Dupont 2000 & $55 / 99$ & $55 / 105$ & & & 7.96 & $1.06(0.82$ to 1.37$)$ \\
\hline Subtotal $(95 \% \mathrm{CI})$ & 919 & 951 & & & 33.43 & 1.09 (0.94 to 1.27$)$ \\
\hline
\end{tabular}

Total events: 236 (monotherapy), 221 (combination therapy) Test for heterogeneity: $\chi^{2}=14.73, \mathrm{df}=18, \mathrm{P}=0.68, I^{2}=0 \%$

Test for overall effect: $z=1.14, P=0.26$

\section{Different $\beta$ lactam}

Naime Libien 1992

Moreno 1997

Sanfilippo 1989

Thompson 1993

Aguilar 1992

Wing 1998

Rasmussen 1986

Yellin 1993

Havig 1973

Limson 1988

Holloway 1985

Rapp 1984

Bergeron 1988

Cone 1985

Landau 1990

Arich 1987

Speich 1998

Gomez 1990

lakovlev 1998

Vergnon 1985

Verzasconi 1995

Gerecht 1989

Mandell 1987

Muller 1987

Koehler 1990

Martin 1991

McCormick 1997

Hoepelman 1988

Brown 1984

Warren 1983

Alvarez Lerma 2001

Felisart 1985

Mouton 1995

Jaspers 1998

Thompson 1990

Duff 1982

Finer 1992

Stille 1992

Sieger 1997

Rubinstein 1995

Mouton 1990

Smith 1984

Subtotal $(95 \% \mathrm{Cl})$

$0 / 15$

$1 / 30$

$0 / 13$

2/80

$0 / 19$

$0 / 16$

$6 / 117$

$1 / 29$
$1 / 56$

$1 / 24$

$2 / 20$

$2 / 15$

2/17

$2 / 37$

$3 / 21$
$4 / 20$

$3 / 25$

$4 / 41$

$6 / 39$

$4 / 48$

$7 / 16$
$6 / 45$

$4 / 24$

$4 / 24$
$7 / 52$
$16 / 73$

$16 / 73$

$13 / 63$

$10 / 52$

$13 / 65$

$8 / 45$

$7 / 18$

$13 / 56$

$10 / 57$
$9 / 37$

$14 / 111$

$12 / 39$

$15 / 49$

$12 / 31$

$30 / 106$

$40 / 267$

$39 / 105$

$35 / 96$

Total events: 410 (monotherapy), 507 (combination therapy) Test for heterogeneity: $\chi^{2}=40.77, \mathrm{df}=41, \mathrm{P}=0.48, I^{2}=0 \%$ Test for overall effect: $z=4.65, P<0.00001$

Total $(95 \% \mathrm{Cl})$

3414

Total events: 646 (monotherapy), 728 (combination therapy)

Test for heterogeneity: $\chi^{2}=69.05, \mathrm{df}=60, \mathrm{P}=0.20, I^{2}=13.1 \%$

Test for overall effect: $z=2.61, P=0.009$
3202

$0 / 15$

$0 / 28$
$1 / 13$

$0 / 40$

$3 / 17$

2/14

$0 / 62$

$1 / 34$

$2 / 26$

$3 / 20$

$3 / 18$

$5 / 30$
$4 / 19$

$3 / 20$

$5 / 22$

$5 / 39$

$10 / 47$

$4 / 14$
$8 / 42$

$13 / 22$

$9 / 58$

$5 / 33$

$6 / 64$
$8 / 42$

$8 / 63$

$9 / 16$

$12 / 64$

$20 / 59$

$18 / 36$
$20 / 118$

$15 / 40$

$14 / 47$

$16 / 43$

$22 / 195$
$26 / 151$

$43 / 105$

$59 / 238$

$43 / 106$

$58 / 99$

$$
\begin{array}{ll} 
& \\
& \\
& \\
\text { py) } & \\
& \\
&
\end{array}
$$
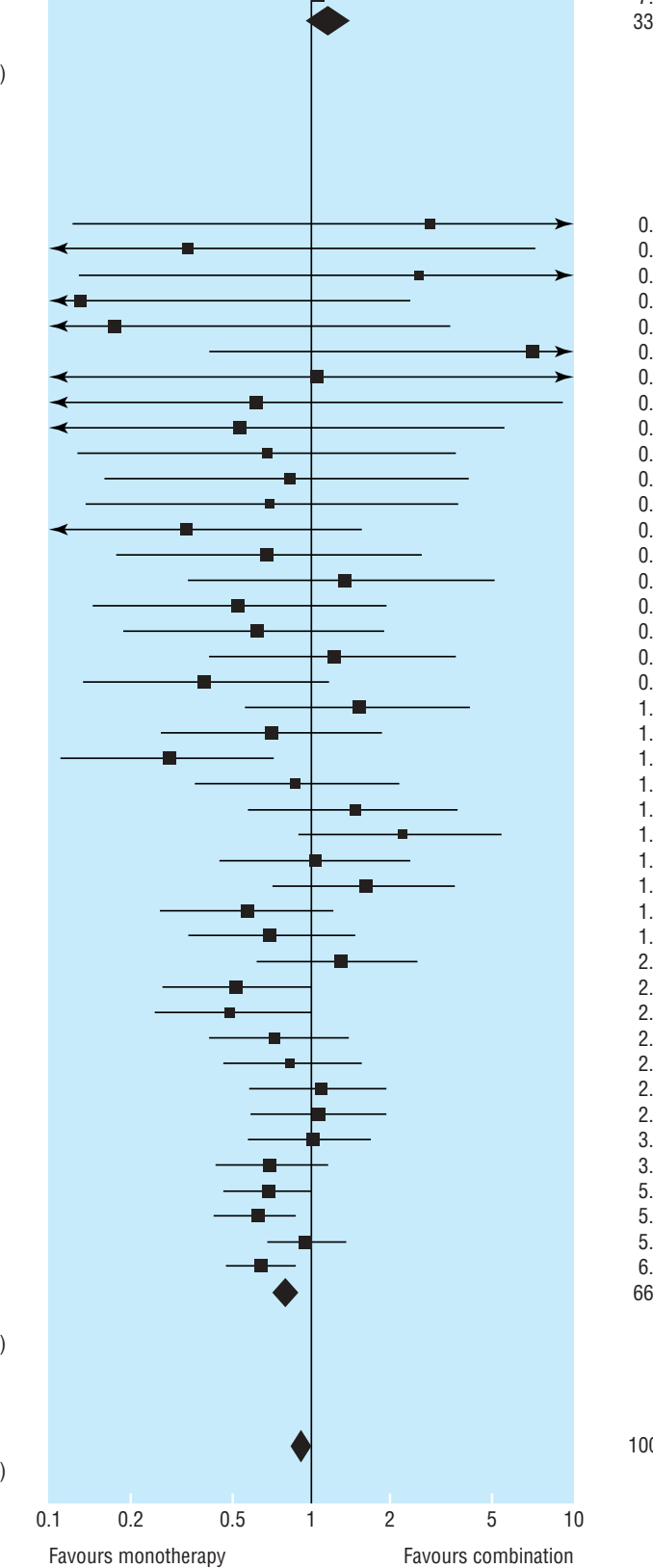

Not estimable

$2.81(0.12$ to 66.17$)$

0.33 (0.01 to 7.50$)$

$2.53(0.12$ to 51.50$)$

0.13 (0.01 to 2.32)

0.18 (0.01 to 3.39$)$

6.94 (0.40 to 121.21)

1.03 (0.07 to 15.77)

0.61 (0.04 to 9.39$)$

$0.54(0.05$ to 5.60$)$

0.67 (0.12 to 3.57$)$

$0.80(0.15$ to 4.18$)$

0.71 (0.13 to 3.72$)$

0.32 (0.07 to 1.56$)$

0.68 (0.17 to 2.65)

$1.33(0.34$ to 5.21$)$

0.53 (0.14 to 1.96$)$

$0.60(0.19$ to 1.90$)$

$1.20(0.40$ to 3.61$)$

0.39 ( 0.13 to 1.16$)$

1.53 (0.56 to 4.15$)$

0.70 (0.26 to 1.85$)$

0.28 (0.11 to 0.74$)$

0.87 (0.35 to 2.16)

1.45 (0.58 to 3.62 )

2.20 (0.89 to 5.43$)$

1.01 (0.44 to 2.33$)$

1.58 (0.70 to 3.54$)$

$0.56(0.26$ to 1.21$)$

0.69 (0.34 to 1.42)

1.24 (0.62 to 2.49)

$0.52(0.27$ to 1.01$)$

$0.49(0.25$ to 0.94$)$

$0.74(0.40$ to 1.40$)$

$0.82(0.44$ to 1.52$)$

1.03 (0.56 to 1.89$)$

1.04 (0.58 to 1.87$)$

$0.97(0.56$ to 1.67$)$

$0.97(0.56$ to 1.67$)$

$0.69(0.47$ to 1.01$)$

$0.60(0.42$ to 0.87$)$

0.92 (0.65 to 1.29 )

0.62 (0.46 to 0.85 )

0.76 (0.68 to 0.86 )

100.00

0.87 ( 0.78 to 0.97$)$

Fig 3 Clinical failure in comparison of $\beta$ lactam monotherapy $v \beta$ lactam-aminoglycoside combination therapy for treatment of sepsis. Log scale of relative risks (95\% confidence intervals), random effect model. Studies ordered by weight 


\begin{tabular}{lcc}
\hline $\begin{array}{l}\text { Study } \\
\text { or subcategory }\end{array}$ & $\begin{array}{c}\text { Monotherapy } \\
\text { No/Total }\end{array}$ & $\begin{array}{c}\text { Combination } \\
\text { therapy } \\
\text { No/Total }\end{array}$ \\
01 Same $\beta$ lactam & $0 / 12$ & $0 / 12$ \\
Abrams 1979 & $0 / 45$ & $0 / 45$ \\
Ribera 1996 & $0 / 23$ & $1 / 23$ \\
Sexton 1998 & $4 / 10$ & $0 / 10$ \\
Sculier 1982 & $1 / 33$ & $1 / 41$ \\
Korzeniowski 1982 & $13 / 28$ & $0 / 17$ \\
Sage 1987 & $3 / 11$ & $2 / 16$ \\
Sukoh 1994 & $10 / 22$ & $3 / 23$ \\
Klastersky 1973 & $5 / 24$ & $8 / 19$ \\
Piccart 1984 & $7 / 31$ & $14 / 39$ \\
Takamoto 1994 & $17 / 60$ & $7 / 32$ \\
D'Antonio 1992 & $9 / 22$ & $10 / 28$ \\
Sandberg 1997 & $8 / 26$ & $16 / 33$ \\
Mergoni 1987 & $8 / 22$ & $17 / 44$ \\
Coppens 1983 & 369 & 382 \\
Subtotal $(95 \%$ Cl) & & \\
\end{tabular}

Total events: 65 (monotherapy), 79 (combination therapy) Test for heterogeneity: $\chi^{2}=19.34, \mathrm{df}=11, \mathrm{P}=0.06, I^{2}=43.1 \%$ Test for overall effect: $z=0.37, P=0.71$

\section{Different $\beta$ lactam}

Landau 1990

Naime Libien 1992

Arich 1987

Moreno 1997

Speich 1998

Verzasconi 1995

Trujillo 1992

Wiecek 1986

Bergeron 1988

Holloway 1985

Koehler 1990

Limson 1988

Wing 1998

Smith 1984

Aguilar 1992

Warren 1983

Stille 1992

Gerecht 1989

lakovlev 1998

Finer 1992

Gomez 1990

Jaspers 1998

Mouton 1995

Rubinstein 1995

Mandell 1987

Rapp 1984

Alvarez Lerma 2001

Mouton 1990

Sieger 1997

Subtotal $(95 \% \mathrm{Cl})$

Total events: 213 (monotherapy), 253 (combination therapy) Test for heterogeneity: $\chi^{2}=28.99, \mathrm{df}=26, \mathrm{P}=0.31, I^{2}=10.3 \%$ Test for overall effect: $z=2.46, P=0.01$

Total $(95 \% \mathrm{Cl})$

Total events: 298 (monotherapy), 332 (combination therapy) Test for heterogeneity: $\chi^{2}=49.81, \mathrm{df}=38, \mathrm{P}=0.10, I^{2}=23.7 \%$

Test for overall effect: $z=1.71, P=0.09$
1814

$\begin{array}{cc}0 / 19 & 0 / 20 \\ 0 / 6 & 0 / 1 \\ 0 / 25 & 1 / 22 \\ 1 / 20 & 0 / 21 \\ 0 / 14 & 1 / 14 \\ 6 / 39 & 0 / 34 \\ 0 / 16 & 5 / 14 \\ 1 / 10 & 1 / 10 \\ 1 / 19 & 5 / 13 \\ 2 / 15 & 3 / 18 \\ 5 / 43 & 2 / 43 \\ 3 / 21 & 3 / 20 \\ 4 / 100 & 4 / 49 \\ 3 / 33 & 8 / 37 \\ 3 / 19 & 7 / 17 \\ 8 / 49 & 4 / 50 \\ 5 / 152 & 7 / 113 \\ 4 / 24 & 7 / 22 \\ 6 / 44 & 7 / 43 \\ 7 / 87 & 8 / 59 \\ 9 / 39 & 6 / 39 \\ 7 / 22 & 7 / 19 \\ 11 / 76 & 11 / 80 \\ 15 / 217 & 15 / 219 \\ 12 / 57 & 14 / 64 \\ 7 / 17 & 12 / 18 \\ 13 / 51 & 21 / 45 \\ 32 / 105 & 27 / 106 \\ 48 / 106 & 67 / 105 \\ 1445 & 1315 \\ & \\ & \\ \text { py), } 253 \text { (combination therapy) } \\ \mathrm{P}=0.01 \\ \end{array}$

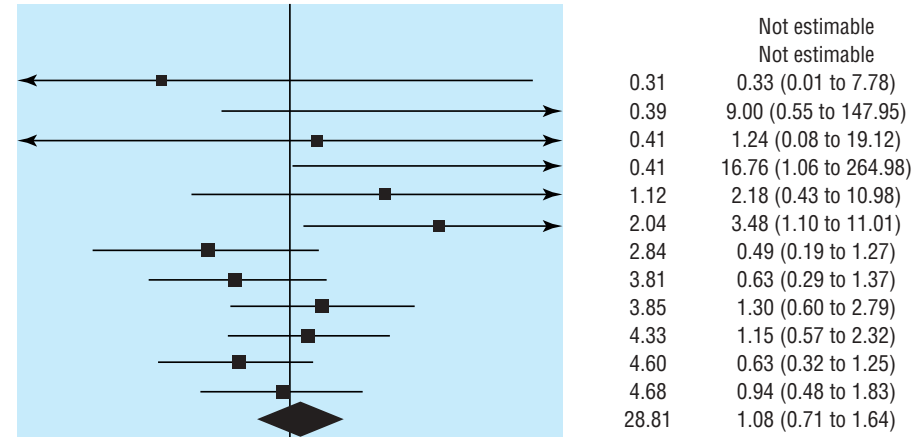

Not estimable

Not estimable

0.29 (0.01 to 6.89$)$

3.14 ( 0.14 to 72.92$)$ $0.33(0.01$ to 7.55$)$

1.38 (0.66 to 194.78$)$ $0.08(0.00$ to 1.33$)$

1.00 (0.07 to 13.87$)$

0.14 (0.02 to 1.04$)$

0.80 (0.15 to 4.18$)$

$2.50(0.51$ to 12.19$)$

0.95 (0.22 to 4.18$)$

0.49 (0.13 to 1.88 )

0.42 (0.12 to 1.45$)$

$0.38(0.12$ to 1.25$)$

2.04 (0.66 to 6.34)

0.53 (0.17 to 1.63 )

0.52 (0.18 to 1.55$)$

0.84 ( 0.31 to 2.29$)$

$0.59(0.23$ to 1.55$)$

1.50 (0.59 to 3.81$)$

0.86 ( 0.37 to 2.02$)$

1.05 (0.49 to 2.28)

$1.01(0.51$ to 2.01$)$

0.96 (0.49 to 1.91$)$

0.62 (0.32 to 1.19$)$

0.55 (0.31 to 0.96$)$

$1.20(0.77$ to 1.85$)$

$0.71(0.55$ to 0.91$)$

0.80 (0.66 to 0.95 )

100.0

0.86 (0.72 to 1.02$)$

Fig 4 Bacteriological failure in comparison of $\beta$ lactam monotherapy $v \beta$ lactam-aminoglycoside combination therapy for treatment of sepsis. Log scale of relative risks ( $95 \%$ confidence intervals), random effect model. Studies ordered by weight

comparing the same $\beta$ lactam (relative risk $1.02,0.76$ to 1.38 ), but it is of concern that studies comparing different $\beta$ lactams $(0.85$, 0.69 to 1.05 ) may not detect important harm to patients.

Our assessment of treatment effects for patients with $P$ aeruginosa, Gram negative, and blood infections relies on subgroup analysis. We did not detect an advantage for combination therapy among these patients. Only few patients with documented $P$ aeruginosa infections could be evaluated. The types of infections addressed by included studies-severe infections acquired in the hospital or pneumonia acquired in intensive care units-suggest that further infections were caused by this pathogen.

\section{Does further evidence support our findings?}

Suggestions for combination treatment for $P$ aeruginosa rely mostly on a prospective observational study of 200 patients with $P$ aeruginosa bacteraemia, in which combination therapy was associated with improved survival and in which synergistic com- 
Table 2 All cause fatality in comparison of $\beta$ lactam monotherapy $v \beta$ lactam-aminoglycoside combination therapy for treatment of sepsis: subgroup analyses

\begin{tabular}{|c|c|c|c|c|c|c|}
\hline & \multicolumn{3}{|c|}{ Same $\beta$ lactam } & \multicolumn{3}{|c|}{ Different $\beta$ lactam } \\
\hline & Studies & Patients & RR $(95 \% \mathrm{CI})$ & Studies & Patients & RR $(95 \% \mathrm{Cl})$ \\
\hline Pseudomonas aeruginosa infections & 1 & 9 & NA & 2 & 29 & 1.50 (0.07 to 32.84$)$ \\
\hline Gram negative infections & 3 & 117 & 0.58 (0.08 to 4.43$)$ & 5 & 313 & 1.20 (0.79 to 1.83$)$ \\
\hline Bacteraemia* $^{*}$ & 1 & 11 & NA & 5 & 193 & $1.40(0.72$ to 2.71$)$ \\
\hline Non-urinary tract infections & 3 & 351 & 0.89 (0.53 to 1.49$)$ & 13 & 1458 & $0.76(0.57$ to 1.03$)$ \\
\hline Staphylococcus aureus endocarditis & 3 & 188 & $0.44(0.12$ to 1.59$)$ & 0 & 0 & - \\
\hline
\end{tabular}

NA=not assessed.

*Excluding studies restricted to Gram positive infections.

binations were associated with a trend for improved survival compared with non-synergistic combinations ${ }^{87}$ A similar study focusing on Klebsiella bacteraemia found an advantage for combination therapy only among patients with hypotension, ${ }^{15}$ while other studies have not found such an advantage. ${ }^{10-12} 88$

Immunocompromised patients are the most likely to gain from enhanced bactericidal activity possibly offered by $\beta$ lactamaminoglycoside combination therapy. ${ }^{9}$ In a comparison of $\beta$ lactam monotherapy with $\beta$ lactam-aminoglycoside combination therapy restricted to patients with neutropenia we found no advantage to combination treatment. ${ }^{89}$ Although the approach to the management of patients with and without neutropenia is separated in clinical practice, this similarity supports a biological basis underlying our results.

\section{Implications for practice}

Antibiotic treatment is nearly always instituted empirically and is often continued with no isolate to direct specific treatment. Most trials assessed this scenario and do not support a benefit for combination therapy. Clinicians may still opt for combination empirical treatment to increase the probability of appropriate empirical treatment, which has indeed been shown to improve survival. $^{90}$ 91 Current evidence suggests that aminoglycoside monotherapy may be inadequate for infections outside the urinary tract. ${ }^{10293}$ Thus, for the purpose of enhancing antimicrobial spectrum, aminoglycosides may constitute a poor choice. Combination treatment is considered for patients with severe infections. However, these are the patients most prone to harm by the addition of an aminoglycoside. With no proved survival benefit, combination therapy may be unjustifiable. Several studies, included in the overall and subgroup analyses, directly assessed semiempirical combination versus monotherapy. These, similarly, do not support combination therapy for specific pathogens, when detected.

\section{Implications for further research}

Should further research be conducted to assess combination versus monotherapy? Novel $\beta$ lactams should not be compared with older generation $\beta$ lactams or penicillins combined with aminoglycosides. The reason for further trials assessing the addition of an aminglycoside to a $\beta$ lactam seems dubious as well. The relative risks and confidence intervals available with all current evidence do not point to a potential benefit overall or in specific subgroups of patients. Furthermore, assessment of efficacy among subgroups such as patients with $P$ aeruginosa infections probably requires an unachievable number of patients treated empirically at the time benefit of antibiotic treatment is most evident.

We included in our review a small subset of trials that assessed the value of addition of an aminoglycoside in Gram positive infections. Three studies assessed staphylococcal endocarditis, ${ }^{21} 4863$ one study assessed any staphylococcal infection, ${ }^{32}$ and one assessed streptococcal endocarditis. ${ }^{69} \beta$ lactam-aminoglycoside treatment is well ingrained in existing

Table 3 Clinical failure in comparison of $\beta$ lactam monotherapy $v \beta$ lactam-aminoglycoside combination therapy for treatment of sepsis: subgroup analyses

\begin{tabular}{|c|c|c|c|c|c|c|}
\hline & \multicolumn{3}{|c|}{ Same $\beta$ lactam } & \multicolumn{3}{|c|}{ Different $\beta$ lactam } \\
\hline & Studies & Patients & RR $(95 \%$ Cl) & Studies & Patients & RR $(95 \%$ Cl) \\
\hline Pseudomonas aeruginosa infections & 6 & 124 & 1.01 (0.68 to 1.49$)$ & 12 & 302 & 1.09 (0.65 to 1.83$)$ \\
\hline Gram negative infections & 10 & 432 & 1.15 (0.82 to 1.59$)$ & 18 & 1403 & $0.88(0.67$ to 1.17$)$ \\
\hline Bacteraemia* $^{*}$ & 5 & 141 & 1.22 (0.59 to 2.52$)$ & 17 & 624 & $0.67(0.48$ to 0.93$) \dagger$ \\
\hline Non-urinary tract infections§ & 10 & 1148 & $1.03(0.66$ to 1.60$)$ & 31 & 2945 & $0.71(0.61$ to 0.82$) \dagger$ \\
\hline Gram positives/endocarditis & 5 & 305 & 0.71 (0.41 to 1.22$)$ & 0 & 0 & - \\
\hline
\end{tabular}

Gam positives/endocarditis

$\dagger P<0.05$.

$\S$ Significant advantage for monotherapy when all studies are combined, $P=0.01$.

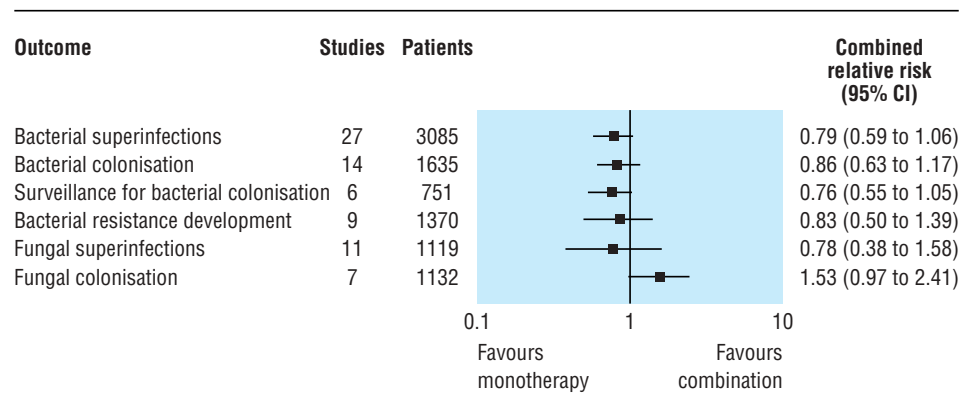

Fig 5 Summary relative risks for outcome relating to resistance development in comparison of $\beta$ lactam monotherapy $v \beta$ lactam-aminoglycoside combination therapy for treatment of sepsis. Log scale of relative risks ( $95 \%$ confidence intervals), random effect model. Studies ordered by weight 


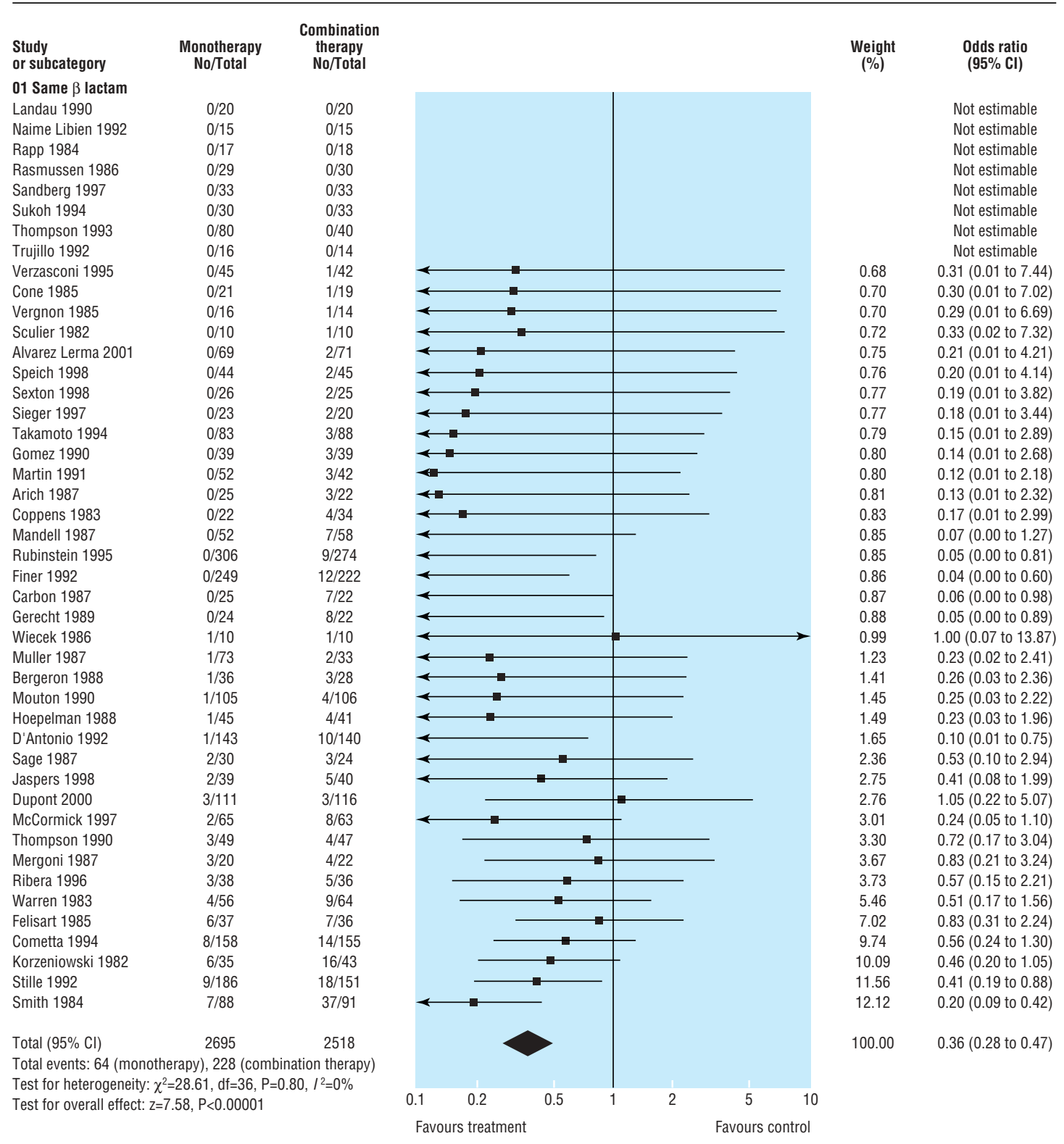

Fig 6 Adverse events: nephrotoxicity in comparison of $\beta$ lactam monotherapy $v \beta$ lactam-aminoglycoside combination therapy for treatment of sepsis. Log scale of relative risks ( $95 \%$ confidence intervals), random effect model. Studies ordered by weight

guidelines and clinical practice with these infections, ${ }^{94}$ yet our results do not point to a clinical benefit with combination therapy. With these infections, further studies should assess whether the addition of an aminoglycoside is justified.

We thank the Cochrane Infectious Diseases Group for their support, review process, and help in obtaining papers; all the authors who responded for our requests for additional data; and Rika Fujiya, who translated the Japanese studies. The protocol for this review with the detailed search strategy and methods is published in the Cochrane Library. ${ }^{95}$ The complete review will be published in the forthcoming issue of the Cochrane Library. Contributors: MP and LL performed the search. All authors selected trials for inclusion, performed data extraction and quality assessment of the trials, and analysed the data. MP and LL contacted authors and requested missing data. All authors participated drafting the manuscript for the Cochrane review and for the journal article. MP is guarantor for the article.

Funding: This work was supported by an EU 5th framework grant (TREAT project, grant No 1999-11459).

Competing interests: None declared.

Ethical approval: Not required.
1 Giamarellou H, Zissis NP, Tagari G, Bouzos J. In vitro synergistic activities of aminoglycosides and new beta-lactams against multiresistant Pseudomonas aeruginosa. Antimicrob Agents Chemother 1984:25:534-6.

2 Giamarellou H. Aminoglycosides plus beta-lactams against gram-negative organisms. Evaluation of in vitro synergy and chemical interactions. Am J Med 1986;80:126-37.

3 Klastersky J, Meunier-Carpentier F, Prevost JM. Significance of antimicrobial synergism for the outcome of gram negative sepsis. Am J Med Sci 1977;273:157-67.

4 Klastersky J, Zinner SH. Synergistic combinations of antibiotics in gram-negative bacillary infections. Reu Infect Dis 1982;4:294-301.

5 Den Hollander JG, Horrevorts AM, van Goor ML, Verbrugh HA, Mouton JW. Synergism between tobramycin and ceftazidime against a resistant Pseudomonas aeruginosa strain, tested in an in vitro pharmacokinetic model. Antimicrob Agents Chemother 1997;41:95-100.

6 Mouton JW. Combination therapy as a tool to prevent emergence of bacterial resistance. Infection 1999;27:S24-8.

7 Wu YL, Scott EM, Po AL, Tariq VN. Ability of azlocillin and tobramycin in combination to delay or prevent resistance development in Pseudomonas aeruginosa.J Antimicrob Chemother 1999;44:389-92.

8 Niederman MS, Mandell LA, Anzueto A, Bass JB, Broughton WA, Campbell GD, et al. Guidelines for the management of adults with community-acquired pneumonia. Diagnosis, assessment of severity, antimicrobial therapy, and prevention. Am J Respir Crit nosis, assessment of severity,

9 Moellering RS. Principles of anti-infective therapy. In: Mandell GL, Bennet JE, Dolin R, eds. Mandell, Douglas, and Bennet's principles and practice of infectious diseases. 5th ed. Philadelphia: Churchill Livingstone, 2000. 
Table 4 Characteristics of included studies: methods

\begin{tabular}{|c|c|c|c|c|c|c|c|}
\hline \multirow[b]{2}{*}{ Study } & \multirow[b]{2}{*}{ Location } & \multirow[b]{2}{*}{ Extra data* } & \multirow[b]{2}{*}{ Randomisation procedure } & \multirow[b]{2}{*}{ Blinding } & \multicolumn{2}{|c|}{ Lost to follow up } & \multirow[b]{2}{*}{ Length of follow up } \\
\hline & & & & & Fatality† & Clinical failure & \\
\hline Abrams $^{21} 1979$ & USA & & No data & Open & $0 \mathrm{PP} \ddagger$ & $0 \mathrm{PP}$ & 4 weeks \\
\hline $\begin{array}{l}\text { Aguilar }{ }^{22} 1992 \\
\end{array}$ & Mexico & Lilacs & No data & Open & - & $\begin{array}{c}\text { No data, presumed } \\
\text { ITT§ }\end{array}$ & 10 days \\
\hline Alvarez Lerma ${ }^{23} 2001$ & Multicentre, Spain & Methods & $\begin{array}{l}\text { Computer generated, central } \\
\text { randomisation concealed by } \\
\text { sealed opaque envelopes }\end{array}$ & Open & ITT & $17 \%$ & 14 days after treatment \\
\hline Arich $^{24} 1987$ & France & Methods & $\begin{array}{l}\text { Random number table, } \\
\text { concealed by sealed opaque } \\
\text { envelopes }\end{array}$ & Open & $28 \%$ & $28 \%$ & No data \\
\hline Bergeron $^{25} 1988$ & Multicetre, Canada & No & No data & Open & $14 \%$ & $13 \%$ & 4-6 weeks after treatment \\
\hline Biglino $^{26} 1991$ & Italy & No & No data & Open & - & No data, presumed ITT & \\
\hline Brown $^{27} 1984$ & USA & No & $\begin{array}{l}\text { Random number table } \\
\text { without further detail }\end{array}$ & $\begin{array}{l}\text { Outcome } \\
\text { assessors } \\
\text { blinded }\end{array}$ & $29 \%$ & $29 \%$ & In hospital stay \\
\hline Carbon $^{28} 1987$ & Multicentre, France & No & No data & Open & No data, presumed ITT & No data, presumed ITT & No data \\
\hline Cardozo $^{29} 2001$ & Paraguay & $\begin{array}{l}\text { Methods, } \\
\text { outcomes } \\
\text { Lilacs }\end{array}$ & $\begin{array}{l}\text { Numerical assignation } \\
\text { without further detail }\end{array}$ & Open & No data, presumed ITT & No data, presumed ITT & No data \\
\hline $\begin{array}{l}\text { Cometta }^{30} \\
1994\end{array}$ & $\begin{array}{l}\text { Multicentre, } \\
\text { Switzerland }\end{array}$ & $\begin{array}{l}\text { Methods, } \\
\text { outcomes }\end{array}$ & $\begin{array}{l}\text { Random number table, } \\
\text { concealed by sealed opaque } \\
\text { envelopes }\end{array}$ & Open & $7 \%$ & $7 \%$ & No data \\
\hline Cone $^{31} 1985$ & USA & No & No data & Open & - & $30 \%$ & End of treatment \\
\hline Coppens $^{32} 1983$ & Belgium & No & $\begin{array}{l}\text { Consecutively numbered } \\
\text { envelopes }\end{array}$ & Open & - & $17 \%$ & No data \\
\hline D'Antonio $^{33} 1992$ & Italy & $\begin{array}{l}\text { Methods, } \\
\text { outcomes }\end{array}$ & $\begin{array}{l}\text { Random number table } \\
\text { concealed by sealed opaque } \\
\text { envelopes }\end{array}$ & Open & ITT & $5 \%$ & End of treatment \\
\hline Duff $^{34} 1982$ & USA & $\begin{array}{l}\text { Methods, } \\
\text { outcomes }\end{array}$ & $\begin{array}{l}\text { Hospitalisation number } \\
\text { without further detail }\end{array}$ & Open & ITT & ITT & 24 hours after treatment \\
\hline Dupont $^{35} 2000$ & Multicentre, France & No & $\begin{array}{l}\text { Computer generated, central } \\
\text { randomisation }\end{array}$ & $\begin{array}{l}\text { Outcome } \\
\text { assessors } \\
\text { blinded }\end{array}$ & $6 \%$ & $15 \%$ & 4 weeks after treatment \\
\hline Felisart $^{36} 1985$ & Spain & No & $\begin{array}{l}\text { Random number table } \\
\text { without further detail }\end{array}$ & Open & ITT & ITT & 48 hours after treatment \\
\hline Finer $^{37} 1992$ & Multicentre, UK & $\begin{array}{l}\text { Methods, } \\
\text { outcomes }\end{array}$ & $\begin{array}{l}\text { Computer generated } \\
\text { concealed by sealed, } \\
\text { opaque envelopes }\end{array}$ & Open & ITT & 12 & 2-4 weeks after treatment \\
\hline Gerecht $^{38} 1989$ & USA & No & $\begin{array}{l}\text { Computer generated } \\
\text { random number table }\end{array}$ & Open & - & $5 \%$ & 8 weeks after treatment \\
\hline Gomez $^{39} 1990$ & Spain & $\begin{array}{l}\text { Methods, } \\
\text { other studies } \\
\text { CL/Embase }\end{array}$ & $\begin{array}{l}\text { Computer generated } \\
\text { concealed by sealed, closed } \\
\text { envelopes }\end{array}$ & Open; & $0 \mathrm{PP}$ & $0 \mathrm{PP}$ & 4 weeks after treatment \\
\hline Havig $^{40} 1973$ & Norway & No & $\begin{array}{l}\text { Randomisation list applied } \\
\text { consecutively }\end{array}$ & Open & $24 \%$ & $24 \%$ & In hospital stay \\
\hline Hoepelman $^{31} 1988$ & Netherlands & $\begin{array}{l}\text { Methods, } \\
\text { outcomes, } \\
\text { other studies }\end{array}$ & $\begin{array}{l}\text { Randomisation list } \\
\text { concealed by sealed opaque } \\
\text { envelopes }\end{array}$ & Open & ITT & ITT & In hospital stay \\
\hline Holloway ${ }^{42} 1985$ & USA & No & No data & Open & - & $23 \%$ & No data \\
\hline lakovlev $^{43} 1998$ & Multicenter, Russia & No & $\begin{array}{l}\text { Envelopes without further } \\
\text { detail }\end{array}$ & Open & - & ITT & 4 weeks after treatment \\
\hline Jaspers $^{44} 1998$ & $\begin{array}{l}\text { Multicentre, } \\
\text { Netherlands }\end{array}$ & Methods & $\begin{array}{l}\text { Random number table; } \\
\text { sealed opaque envelopes }\end{array}$ & Open & ITT & ITT & 4-6 weeks after treatment \\
\hline Klastersky ${ }^{45} 1973$ & Belgium & No & No data & Open & $9 \%$ & $9 \%$ & No data \\
\hline Kljucar $^{46} 1990$ & Germany & $\begin{array}{l}\text { Reprint, } \\
\text { outcomes, } \\
\text { methods }\end{array}$ & $\begin{array}{l}\text { Computer generated code in } \\
\text { consecutive closed } \\
\text { numbered envelopes }\end{array}$ & Open & $0.7 \%$ & $0.7 \%$ & 4-6 after treatment \\
\hline Koehler $^{47} 1990$ & $\begin{array}{l}\text { Multicentre, } \\
\text { Germany }\end{array}$ & CL/Embase & No data & Open & ITT & $12 \%$ & End of treatment \\
\hline Korzeniowski ${ }^{48} 1982$ & Multicentre, USA & No & $\begin{array}{l}\text { Random number table, } \\
\text { central randomisation }\end{array}$ & Open & $3 \%$ & $3 \%$ & 4 weeks after treatment \\
\hline Landau $^{49} 1990$ & Israel & No & $\begin{array}{l}\text { Patient identification } \\
\text { number without further } \\
\text { detail }\end{array}$ & Open & No data, presumed ITT & No data, presumed ITT & No data \\
\hline Limson $^{50} 1988$ & The Philippines & No & No data & Open & - & $26 \%$ & No data \\
\hline Mandell ${ }^{51} 1987$ & Multicentre, Canada & Other studies & $\begin{array}{l}\text { Consecutive sealed } \\
\text { envelopes }\end{array}$ & Open & & $15 \%$ & 4 weeks after treatment \\
\hline Martin $^{52} 1991$ & Belgium & No & Random number table & Open & - & $19 \%$ & 4-6 weeks after treatment \\
\hline McCormick $^{53} 1997$ & Ireland & Methods & $\begin{array}{l}\text { Random numbers table } \\
\text { concealed by sealed opaque } \\
\text { envelopes }\end{array}$ & Open & $13 \%$ & $13 \%$ & 2 weeks after treatment \\
\hline Mergonis ${ }^{54} 1987$ & Italy & Methods & $\begin{array}{l}\text { Sealed opaque envelopes } \\
\text { without further detail }\end{array}$ & Open & - & No data, presumed ITT & No data \\
\hline
\end{tabular}




\begin{tabular}{|c|c|c|c|c|c|c|c|}
\hline \multirow[b]{2}{*}{ Study } & \multirow[b]{2}{*}{ Location } & \multirow[b]{2}{*}{ Extra data* } & \multirow[b]{2}{*}{ Randomisation procedure } & \multirow[b]{2}{*}{ Blinding } & \multicolumn{2}{|c|}{ Lost to follow up } & \multirow[b]{2}{*}{ Length of follow up } \\
\hline & & & & & Fatality† & Clinical failure & \\
\hline Moreno $^{55} 1997$ & Spain & Lilacs & No data & Open & - & $17 \%$ & No data \\
\hline Mouton $^{56} 1990$ & Multicentre, France & No & No data & Open & ITT & ITT & No data \\
\hline Mouton $^{57} 1995$ & Multicentre, Europe & No & No data & Open & ITT & $18 \%$ & 2-4 weeks after treatment \\
\hline Muller ${ }^{58} 1987$ & Bicentre, USA & No & $\begin{array}{l}\text { Computer generated lists } \\
\text { without further detail }\end{array}$ & Open & - & $19 \%$ & No data \\
\hline Naime Libien ${ }^{59} 1992$ & Mexico & Lilacs & No data & Open & No data, presumed ITT & No data, presumed ITT & No data \\
\hline Piccart $^{60} 1984$ & Belgium & No & No data & Open & & $19 \%$ & No data \\
\hline Rapp $^{61} 1984$ & USA & No & No data & Open & & ITT & End of treatment \\
\hline Rasmussen $^{62} 1986$ & Denmark & $\begin{array}{l}\text { Methods, } \\
\text { outcomes }\end{array}$ & $\begin{array}{l}\text { Random number table, } \\
\text { concealed by sealed } \\
\text { envelopes }\end{array}$ & Open & $5 \%$ & $5 \%$ & 2 weeks \\
\hline Ribera $^{63} 1996$ & Spain & $\begin{array}{l}\text { Methods, } \\
\text { outcomes }\end{array}$ & $\begin{array}{l}\text { Random number table, } \\
\text { concealed by sealed opaque } \\
\text { envelopes }\end{array}$ & Open & ITT & ITT & 6 months \\
\hline Rubinstein $^{64} 1995$ & Multicentre & $\begin{array}{l}\text { Methods, } \\
\text { outcomes }\end{array}$ & $\begin{array}{l}\text { Computer generated code } \\
\text { concealed with sealed } \\
\text { opaque numbered } \\
\text { envelopes }\end{array}$ & $\begin{array}{l}\text { Outcome } \\
\text { assessors } \\
\text { blinded }\end{array}$ & ITT & $13 \%$ & 2 weeks after treatment \\
\hline Sage $^{65} 1987$ & UK & No & $\begin{array}{l}\text { Pre-prepared envelopes, } \\
\text { without further detail }\end{array}$ & Open & - & $21 \%$ & No data \\
\hline Sandberg ${ }^{66} 1997$ & $\begin{array}{l}\text { Multicentre, } \\
\text { Sweden }\end{array}$ & $\begin{array}{l}\text { Methods, } \\
\text { outcomes }\end{array}$ & $\begin{array}{l}\text { Computer generated lists } \\
\text { concealed by sealed opaque } \\
\text { envelopes }\end{array}$ & Open & ITT & $16 \%$ & 4-6 weeks after treatment \\
\hline Sanfilippo ${ }^{67} 1989$ & USA & Embase & $\begin{array}{l}\text { Computer generated code, } \\
\text { central randomisation }\end{array}$ & $\begin{array}{l}\text { Double blind, } \\
\text { placebo } \\
\text { controlled }\end{array}$ & No data, presumed ITT & No data, presumed ITT & 4 weeks after discharge \\
\hline Sculier $^{68} 1982$ & Belgium & No & No data & Open & ITT & ITT & 1 weeks after treatment \\
\hline Sexton $^{69} 1998$ & Multicentre, USA & No & No data & Open & 24 & 24 & 3 months \\
\hline Sieger $^{70} 1997$ & Multicentre, USA & No & No data & Open & ITT & ITT & 1 month \\
\hline Smith $^{71} 1984$ & USA & No & $\begin{array}{l}\text { Random number table, } \\
\text { central randomisation. } \\
\text { Drugs administered in } \\
\text { identically labelled and } \\
\text { coloured antibiotic bottles }\end{array}$ & $\begin{array}{l}\text { Double blind, } \\
\text { placebo } \\
\text { controlled }\end{array}$ & $6.5 \%$ & $2.5 \%$ & 2-4 days after treatment \\
\hline Speich $^{72} 1998$ & $\begin{array}{l}\text { Multicentre, } \\
\text { Switzerland }\end{array}$ & $\begin{array}{l}\text { Methods, } \\
\text { outcomes }\end{array}$ & $\begin{array}{l}\text { Computer generated code } \\
\text { concealed by sealed opaque } \\
\text { envelopes }\end{array}$ & Open & ITT & $6 \%$ & $\begin{array}{l}\text { 10-14 days after } \\
\text { treatment }\end{array}$ \\
\hline Stille $^{73} 1992$ & $\begin{array}{l}\text { Multicentre, } \\
\text { Germany/ Austria }\end{array}$ & No & $\begin{array}{l}\text { Computer generated list, } \\
\text { without further detail }\end{array}$ & Open & ITT & ITT & 1-3 days after treatment \\
\hline Sukoh $^{74} 1994$ & Japan & Methods & $\begin{array}{l}\text { Envelopes, without further } \\
\text { detail }\end{array}$ & Open & - & ITT & No data \\
\hline Takamoto $^{75} 1994$ & Multicentre, Japan & No & $\begin{array}{l}\text { Computer generated code } \\
\text { concealed in envelopes }\end{array}$ & Open & - & $8 \%$ & No data \\
\hline Thompson ${ }^{76} 1990$ & Multicentre, USA & No & $\begin{array}{l}\text { Computer generated, } \\
\text { without further detail }\end{array}$ & Open & $9 \%$ & $9 \%$ & 3 weeks after treatment \\
\hline Thompson ${ }^{77} 1993$ & Multicentre, USA & No & $\begin{array}{l}\text { Computer generated, } \\
\text { without further detail }\end{array}$ & Open & $18 \%$ & $18 \%$ & 1 month \\
\hline Trujillo $^{78} 1992$ & Mexico & Lilacs & No data & Open & No data, presumed ITT & No data, presumed ITT & No data \\
\hline Vergnon $^{79} 1985$ & France & No & No data & Open & No data, presumed ITT & No data, presumed ITT & End of treatment \\
\hline Verzasconi80 1995 & $\begin{array}{l}\text { Bicentre, } \\
\text { Switzerland }\end{array}$ & No & No data & Single blind & & 6 & No data \\
\hline Warren $^{81} 1983$ & USA & No & $\begin{array}{l}\text { Random numbers contained } \\
\text { within consecutively } \\
\text { numbered sealed envelopes }\end{array}$ & Open & $2 \%$ & $2 \%$ & 2 weeks after treatment \\
\hline Wiecek ${ }^{82} 1986$ & Poland & No & No data & Open & No data, presumed ITT & No data, presumed ITT & 3 weeks \\
\hline Wing $^{83} 1998$ & Bicentre. USA & Outcomes & $\begin{array}{l}\text { Computer generated } \\
\text { random number table } \\
\text { concealed by sealed opaque } \\
\text { envelopes }\end{array}$ & Open & ITT & ITT & 2 weeks after treatment \\
\hline Yellin $^{84} 1993$ & USA & Methods & $\begin{array}{l}\text { Random number table, } \\
\text { central randomisation }\end{array}$ & Provider blinded & $15 \%$ & $15 \%$ & 6 weeks \\
\hline
\end{tabular}

\section{$\mathrm{PP}=$ per protocol; ITT=intention to treat.}

${ }^{*}$ Complementary data from authors. Source database listed when article was not available from Medline (CL=Cochrane Library; Ref=reference search). Several additional articles, available in Medline, identified through reference search and retrieved from Medline.

†For studies reporting comparative fatality.

†Trials randomised patients at onset of infectious episode and assessed only patients with specific isolate or diagnosis. No drop outs among patients defined assessable by protocol.

$\S S$ Study referred only to "included" patients, without specifying explicitly number of randomised and assessed patients. No referral to drop outs. Study was assessed as intention to treat.

10 Leibovici L, Paul M, Poznanski O, Drucker M, Samra Z, Konigsberger H, et al. Monotherapy versus beta-lactam-aminoglycoside combination treatment for gramnegative bacteraemia: a prospective, observational study. Antimicrob Agents Chemother 1997;41:1127-33.

11 Siegman-Igra Y, Ravona R, Primerman H, Giladi M. Pseudomonas aeruginosa bacteraemia: an analysis of 123 episodes, with particular emphasis on the effect of antibiotic therapy. Int J Infect Dis 1998;2:211-5.
12 Crabtree TD, Pelletier SJ, Gleason TG, Pruett TL, Sawyer RG. Analysis of aminoglycosides in the treatment of gram-negative infections in surgical patients. Arch Surg 1999;134:1293-9.

13 Montravers P, Veber B, Auboyer C, Dupont H, Gauzit R, Korinek AM, et al. Diagnostic and therapeutic management of nosocomial pneumonia in surgical patients: results of the Eole study. Crit Care Med 2002;30:368-75. 


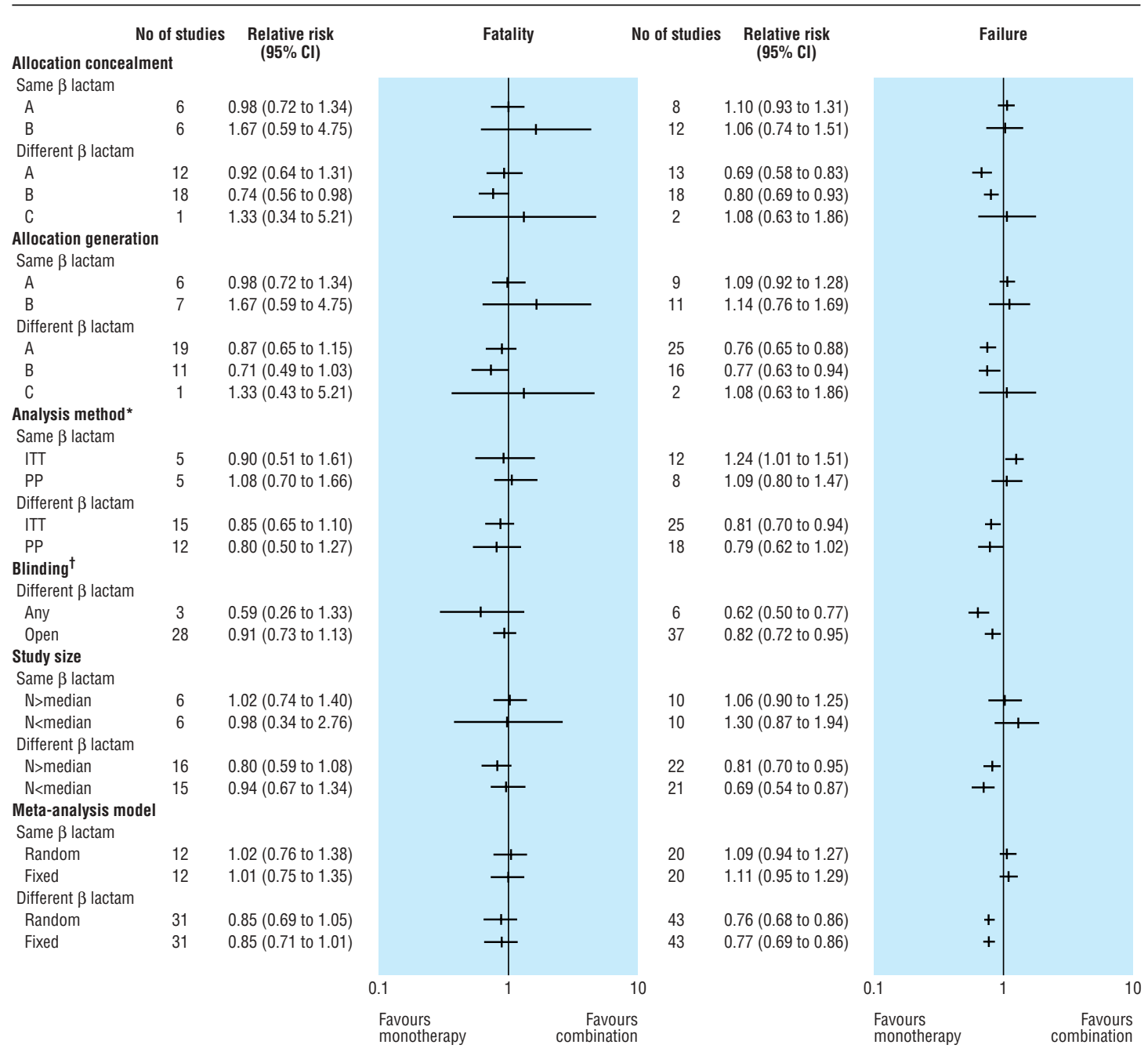

Fig 7 Sensitivity analyses Randomisation methods were classified as $A=$ adequate; $B=$ unknown; $C=$ inadequate ${ }^{85}$ Central randomisation, inaccessible computer randomisation, and sealed opaque envelopes were considered adequate for allocation concealment. Table of random numbers, computer generated lists, and consecutive selection were considered adequate for allocation generation. ${ }^{*}$ Fatality comparison includes studies that reported results for all randomised patients (ITT=intention to treat) $v$ studies reporting results for evaluable patients only (PP=per protocol). Studies that did not state method of analysis and did not refer to drop outs are not included. Failure comparison includes studies that reported results or drop outs for all randomised patients (drop outs counted as failures, ITT) $v$ studies performed per protocol that did not state number of drop outs per study arm (PP). Results with all studies combined in this graph differ from those attained in main comparison because drop outs are counted as failures (relative risk $0.92,0.82$ to 1.03 ). †Comparison for studies comparing same $\beta$ lactam was not performed as only one study used blinding

14 Grasela TH Jr, Welage LS, Walawander CA, Timm EG, Pelter MA, Poirier TI, et al. A nationwide survey of antibiotic prescribing patterns and clinical outcomes in patients with bacterial pneumonia. DICP 1990;24:1220-5

15 Korvick JA, Bryan CS, Farber B, Beam TR Jr, Schenfeld L, Muder RR, et al. Prospective observational study of Klebsiella bacteraemia in 230 patients: outcome for antibiotic combinations versus monotherapy. Antimicrob Agents Chemother 1992;36:2639-44.

16 Leone M, Bourgoin A, Cambon S, Dubuc M, Albanese J, Martin C. Empirical antimicrobial therapy of septic shock patients: adequacy and impact on the outcome. Crit Care Med 2003;31:462-7.

17 Bone RC, Sibbald WJ, Sprung CL. The ACCP-SCCM consensus conference on sepsis and organ failure. Chest 1992;101:1481-3.

18 Higgins JP, Thompson SG, Deeks JJ, Altman DG. Measuring inconsistency in meta-analyses. BMJ 2003;327:557-60.

19 DerSimonian R, Laird N. Meta-analysis in clinical trials. Control Clin Trials 1986;7:17788.

20 Clarke M, Oxman AD, eds. Cochrane reviewers'handbook 4.1.6. Oxford: Update Software, 2003.

21 Abrams B, Sklaver A, Hoffman T, Greenman R. Single or combination therapy of staphylococcal endocarditis in intravenous drug abusers. Ann Intern Med 1979;90:789-91.

22 Ramírez de Aguilar R. [Clinical trial on efficacy and safety of ceftizoxime compared with penicillin-gentamicin of manafing of adult severe infections.] (In Spanish.) Compend Invest Clin Latinoam 1992;12:75-8.

23 Alvarez Lerma F. Efficacy of meropenem as monotherapy in the treatment of ventilator-associated pneumonia.J Chemother 2001;13:70-81.

24 Arich C, Gouby A, Bengler C, Ardilouze JL, Dubois A, Joubert P, et al. [Comparison of the efficacy of cefotaxime alone and the combination cefazolin-tobramycin in the treatment of enterobacterial septicemia.] (In French.) Pathol Biol (Paris) 1987;35:613-5.
25 Bergeron MG, Mendelson J, Harding GK, Mandell L, Fong IW, Rachlis A, et al. Cefoprazone compared with ampicillin plus tobramycin for severe biliary tract infections. Antimicrob Agents Chemother 1988;32:1231-6.

26 Biglino A, Bonasso M, Gioannini P. Imipenem/cilastatin as empirical treatment of severe infections in compromised patients. J Chemother 1991;3 suppl 1:208-12.

27 Brown RB, Lemeshow S, Teres D. Moxalactam vs carbenicillin plus tobramycin: treatment of nosocomial gram-negative bacillary pneumonias in non-neutropenic patients. Curr Ther Res Clin Exp 1984:36:557-64.

28 Carbon C, Auboyer C, Becq Giraudon B, Bertrand P, Gallais H, Mouton Y, et al. Cefotaxime $(\mathrm{C})$ vs cefotaxime + amikacin $(\mathrm{C}+\mathrm{A})$ in the treatment of septicemia due to enterobacteria: a multicenter study Chemioterapia 1987;6(2 suppl):367-8.

29 Cardozo M, Basualdo W, Martínez R, Matsumura K, González-Cabello M, Navarro D, et al. [Evaluation of the association amoxicillin/sulbactam to a amoxicillin/sulbactam more gentamicins in childs with peritonitis of apendicular origin.] (In Spanish.) Pediatr (Asunción) 2001;28:15-9.

30 Cometta A, Baumgartner JD, Lew D, Zimmerli W, Pittet D, Chopart P, et al. Prospective randomized comparison of imipenem monotherapy with imipenem plus netilmicin for treatment of severe infections in nonneutropenic patients. Antimicrob Agents Chemother 1994;38:1309-13.

31 Cone LA, Woodard DR, Stoltzman DS, Byrd RG. Ceftazidime versus tobramycinticarcillin in the treatment of pneumonia and bacteremia. Antimicrob Agents Chemother 1985;28:33-6.

32 Coppens L, Hanson B, Klastersky J. Therapy of staphylococcal infections with cefamandole or vancomycin alone or with a combination of cefamandole and tobramycin. Antimicrob Agents Chemother 1983;23:36-41.

33 D'Antonio D, Fioritoni G, Iacone A, Dell'Isola M, Natale D, D'Arcangelo L, et al. Randomized comparison of ceftriaxone versus ceftriaxone plus amikacin for the empirical 


\section{What is already known on this topic}

Early appropriate antibiotic treatment for severe infections decreases mortality

In vitro studies have shown that the bactericidal activity of a $\beta$ lactam may be enhanced by the addition of an aminogoycoside

Prospective studies have suggested that the combination also has a clinical advantage

\section{What this study adds}

There is no difference in mortality when $\beta$ lactam-aminoglycoside combination therapy is compared with $\beta$ lactam monotherapy

Clinical failure and renal toxicity are more common with combination therapy

$\beta$ lactam-aminoglycoside combination therapy does not improve clinical outcomes in patients with severe infections

treatment of infections in patients with altered host defense: microbiological and clinical evaluation Chemotherapy 1992:38:420-7.

34 Duff P, Keiser JF. A comparative study of two antibiotic regimens for the treatment of operative site infections. Am J Obstet Gynecol 1982;142:996-1003.

35 Dupont H, Carbon C, Carlet J. Monotherapy with a broad-spectrum beta-lactam is a effective as its combination with an aminoglycoside in treatment of severe generalized peritonitis: a multicenter randomized controlled trial. The Severe Generalized Peritonitis Study Group. Antimicrob Agents Chemother 2000;44:2028-33.

36 Felisart J, Rimola A, Arroyo V, Perez-Ayuso RM, Quintero E, Gines P, et al. Cefotaxime is more effective than is ampicillin-tobramycin in cirrhotics with severe infections. Hepatology 1985;5:457-62.

37 Finer N, Goustas P. Ceftazidime versus aminoglycoside and (ureido)penicillin combination in the empirical treatment of serious infection. J Royal Soc Med 1992;85:530-3

38 Gerecht WB, Henry NK, Hoffman WW, Muller SM, LaRusso NF, Rosenblatt JE, et al Prospective randomized comparison of mezlocillin therapy alone with combined ampicillin and gentamicin therapy for patients with cholangitis. Arch Intern Med 1989;149:1279-84

39 Gomez J, Moldenauer F, Ruiz G, Canteras M, Redondo C, Molina B, et al [Monotherapy (ceftazidime) versus combination therapy (cefradine + amikacin) in gram-negative bacteremia. A prospective, randomized study, 1987.] (In Spanish.) Rev Esp Ouimioter 1990;3:35-40.

40 Havig O, Hertzberg J. Effect of ampicillin, chloramphenicol, and penicillinstreptomycin in acute cholecystitis. Scand J Gastroenterol 1973;8:55-8.

41 Hoepelman IM, Rozenberg-Arska M, Verhoef J. Comparison of once daily ceftriaxone with gentamicin plus cefuroxime for treatment of serious bacterial infections. Lancet 1988;:1305-9.

42 Holloway WJ. Treatment of infections in hospitalized patients with ticarcillin plus clavulanic acid. A comparative study. Am J Med 1985;79:168-71.

43 Iakovlev SV, Iakovlev VP, Derevianko, II, Kira EF, Meropenem SG. [Multicenter open randomized trial of meropenem in comparison to ceftazidime and amikacin used in combidomized trial of meropenem in comparison to ceftazidime and amikacin used in co.

44 Jaspers CA, Kieft H, Speelberg B, Buiting A, van MKM, Ruys GJ, et al. Meropenem versus cefuroxime plus gentamicin for treatment of serious infections in elderly patients. Antimicrob Agents Chemother 1998;42:1233-8.

45 Klastersky J, Cappel R, Daneau D. Therapy with carbenicillin and gentamicin for patients with cancer and severe infections caused by gram-negative rods. Cancer 1973;31:331-6.

46 Kljucar S, Heimesaat M, von Pritzbuer E, Bauernfeind A. Comparative clinical trial with ceftazidime (CAZ) versus ceftazidime plus tobramycin (TOB) versus azlocillin (AZL) plus tobramycin in ventilated patients with nosocomial lower respiratory tract infections (LRTI). Abstract 953. 30th Interscience Conference on Antimicrobial Agents and Chemotherapy; 1990; Atlanta, GA. American Society for Microbiology; 1990.

47 Koehler CO, Arnold H. Controlled clinical study of ceftazidime (3 x $1 \mathrm{~g}$ daily) versus piperacillin + tobramycin in patients with nosocomial pneumonia. Int J Exp Clin Chemother 1990;3:211-8.

48 Korzeniowski O, Sande MA. Combination antimicrobial therapy for Staphylococcus aureus endocarditis in patients addicted to parenteral drugs and in nonaddicts: a prospective study. Ann Intern Med 1982;97:496-503.

49 Landau Z, Feld S, Krupsky M. [Ceftriaxone or combined cefazolin-gentamicin for complicated urinary tract infections.] (In Hebrew.) Harefuah 1990;118:152-3.

50 Limson BM, Navarro Almario E, Litam P, Que E, Kua LT. Ceftazidime versus a combination of amikacin and ticarcillin in the treatment of severe infections. Clin Ther 1988; 10:589-93.

51 Mandell LA, Nicolle LE, Ronald AR, Landis SJ, Duperval R, Harding GK, et al. A prospective randomized trial of ceftazidime versus cefazolin/tobramycin in the treatmen of hospitalized patients with pneumonia.J Antimicrob Chemother 1987;20:95-107.
52 Martin PY, Unger PF, Auckenthaler R, Waldvogel FA. [Efficacy and costs of treatment with ceftriaxone compared to ampicillin-gentamycin in acute pyelonephritis.] (In French.) Rev Med Suisse Romande 1991;111:609-17.

53 McCormick PA, Greenslade L, Kibbler CC, Chin JK, Burroughs AK, McIntyre N. A prospective randomized trial of ceftazidime versus netilmicin plus mezlocillin in the empirical therapy of presumed sepsis in cirrhotic patients. Hepatology 1997;25:833-6.

54 Mergoni M, Stocchetti N, De Cristofaro A, Antonioni M, Zuccoli P. Azlocillin versus azlocillin plus amikacin in the treatment of severe infections in intensive care unit patients. Chemioterapia 1987;6:286-9.

55 Moreno A, Vilardell J, Ricart MJ, Claramonte X, Campistol JM, Oppenheimer F. [Efficacy of several empirical antibacterial treatment regimens in renal transplant patients with fever.] (In Spanish.) Rev Espanol Quimioter 1997;10:138-45.

56 Mouton Y, Deboscker Y, Bazin C, Fourrier F, Moulront S, Philippon A, et al. [Prospective, randomized, controlled study of imipenem-cilastatin versus cefotaxime-amikacin in the treatment of lower respiratory tract infection and septicemia at intensive care units.] (In French). Presse Med 1990;19:607-12.

57 Mouton YJ, Beuscart C. Empirical monotherapy with meropenem in serious bacterial infections. Meropenem Study Group. J Antimicrob Chemother 1995;36 sppl A:145-56.

58 Muller EL, Pitt HA, Thompson JE, Jr., Doty JE, Mann LL, Manchester B. Antibiotics in infections of the biliary tract. Surg Gynecol Obstet 1987;165:285-92.

59 Naime Libién J, Vigueras Rendón A, Sánchez Díaz G, Abraham Jalil A. [Clinical study to evaluate efficacy and safety of ceftizoxime compared vs penicillin-gentamicin fixed combination in the treatment of severe respiratory infections.] (In Spanish.) Compend Invest Clin Latinoam 1992;12:42-8.

60 Piccart M, Klastersky J, Meunier F, Lagast H, Van Laethem Y, Weerts D. Single-drug versus combination empirical therapy for gram-negative bacillary infections in febrile cancer patients with and without granulocytopenia. Antimicrob Agents Chemother 1984;26:870-5.

61 Rapp RP, Young B, Foster TS, Tibbs PA, O'Neal W. Ceftazidime versus tobramycin/ticarcillin in treating hospital acquired pneumonia and bacteremia. Phar macotherapy 1984;4:211-5

62 Rasmussen D, Bremmelgaard A, Rasmussen F, Thorup J. Treatment of serious urological infections with cefotaxime compared to ampicillin plus netilmicin. Dan Med Bull 1986;33:49-51.

63 Ribera E, Gomez-Jimenez J, Cortes E, del Valle O, Planes A, Gonzalez-Alujas T, et al. Effectiveness of cloxacillin with and without gentamicin in short-term therapy for right-sided Staphylococcus aureus endocarditis. A randomized, controlled trial. Ann Intern Med 1996:125:969-74

64 Rubinstein E, Lode H, Grassi C, Castelo A, Ward K, Alanko K, et al. Ceftazidime monotherapy vs. ceftriaxone/tobramycin for serious hospital- acquired gram-negative infections. Clin Infect Dis 1995;20:1217-28.

65 Sage R, Nazareth B, Noone P. A prospective randomised comparison of cefotaxime vs. netilmicin vs. cefotaxime plus netilmicin in the treatment of hospitalised patients with serious sepsis. Scand J Infect Dis 1987;19:331-7.

66 Sandberg T, Alestig K, Eilard T, Ek E, Hebelka M, Johansson E, et al. Aminoglycosides do not improve the efficacy of cephalosporins for treatment of acute pyelonephritis in women. Scand J Infect Dis 1997;29:175-9.

67 Sanfilippo JS, Schikler KN. Mezlocillin versus penicillin and tobramycin in adolescent pelvic inflammatory disease: a prospective study. International Pediatrics 1989;4:53-6.

68 Sculier JP, Coppens L, Klastersky J. Effectiveness of mezlocillin and endotracheally administered sisomicin with or without parenteral sisomicin in the treatment of Gramnegative bronchopneumonia. J Antimicrob Chemother 1982;9:63-8.

69 Sexton DJ, Tenenbaum MJ, Wilson WR, Steckelberg JM, Tice AD, Gilbert D, et al Ceftriaxone once daily for four weeks compared with ceftriaxone plus gentamicin once daily for two weeks for treatment of endocarditis due to penicillin-susceptible streptococci. Endocarditis Treatment Consortium Group. Clin Infect Dis 1998;27:1470-4.

70 Sieger B, Berman SJ, Geckler RW, Farkas SA. Empiric treatment of hospital-acquired lower respiratory tract infections with meropenem or ceftazidime with tobramycin: a lower respiratory tract infections with meropenem or ceftazidime with tobramycin: a
randomized study. Meropenem Lower Respiratory Infection Group. Crit Care Med 1997:25:1663-70.

71 Smith CR, Ambinder R, Lipsky JJ, Petty BG, Israel E, Levitt R, et al. Cefotaxime compared with nafcillin plus tobramycin for serious bacterial infections. A randomized, double-blind trial. Ann Intern Med 1984;101:469-77.

72 Speich R, Imhof E, Vogt M, Grossenbacher M, Zimmerli W. Efficacy, safety, and tolerance of piperacillin/tazobactam compared to co-amoxiclav plus an aminoglycoside in the treatment of severe pneumonia. Eur J Clin Microbiol Infect Dis 1998;17:313-7.

73 Stille W, Shah PM, Ullmann U, Hoffstedt B, Kreisl C, Bommersbach B, et al Randomized multicenter clinical trial with imipenem/cilastatin versus cefotaxime/ gentamicin in the treatment of patients with non-life-threatening infections. Eur J Clin Microbiol Infect Dis 1992;11:683-92.

74 Sukoh M, Inoue T, Morita Y, Ito K, Togano Y, Yamanaka K, et al. [Clinical evaluation of combination therapy of sulbactam/cefoperazone and aminoglycoside in respiratory tract infections.] (In Japanese.) Jpn J Antibiot 1994;47:170-80.

75 Takamoto M, Ishibashi T, Toyoshima H, Tanaka H, Tamaru N, Watanabe K, et al. Imipenem/cilastatin sodium alone or combined with amikacin sulfate in respiratory infections. [Japanese]. Jpn J Antibiot 1994;47:1131-44.

76 Thompson JE Jr, Pitt HA, Doty JE, Coleman J, Irving C. Broad spectrum penicillin as an adequate therapy for acute cholangitis. Surg Gynecol Obstet 1990;171:275-82.

77 Thompson JE Jr, Bennion RS, Roettger R, Lally KP, Hopkins JA, Wilson SE. Cefepime for infections of the biliary tract. Surg Gynecol Obstet 1993;177(suppl):30-40.

78 Zavala Trujillo I. [Research on efficacy and safety of ceftizoxime in treating lower respiratory tracta and skin and soft tissues infections.] (In Spanish.) Compend Invest Clin Latinoam 1992;12:31-41.

79 Vergnon JM, Vincent M, Ros A, Brun Y, Brune J. [Comparative clinical trial of cefoperazone versus ampicillin + tobramycin in severe bronchopulmonary and pleural infectious pathology.] (In French.) Rev Pneumol Clin 1985;41:205-11.

80 Verzasconi R, Rodoni P, Monotti R, Marone C, Mombelli G. [Amoxicillin and clavulanic acid versus amoxicillin plus gentamicin in the empirical initial treatment of urinary tract infections in hospitalized patients.] (In German.) Schweiz Med Wochenschr 1995;125:1533-9.

81 Warren JW, Miller EH, Jr., Fitzpatrick B, DiFranco DE, Caplan ES, Tenney JH, et al. A randomized, controlled trial of cefoperazone vs. cefamandole- tobramycin in the treat- 
ment of putative, severe infections with gram- negative bacilli. Rev Infect Dis 1983;5(suppl 1):173-80S

82 Wiecek A, Kokot F, Andrzejowska H, Grzeszczak W. [Clinical evaluation of ceftazidime and the combined administration of cefotaxime and tobramycin in the treatment of urinary tract infections. Prospective and randomized studies.] (In Polish.) Pol Tyg Lek $1986 ; 41: 1242-6$.

83 Wing DA, Hendershott CM, Debuque L, Millar LK. A randomized trial of three antibiotic regimens for the treatment of pyelonephritis in pregnancy. Obstet Gynecol 1998;92:249-53.

84 Yellin AE, Berne TV, Appleman MD, Heseltine PN, Gill MA, Okamoto MP, et al. A randomized study of cefepime versus the combination of gentamicin and mezlocillin as an adjunct to surgical treatment in patients with acute cholecystitis. Surg Gynecol Obstet adjunct to surgical treatment in patients with acute cholecystitis. Surg Gynecol Obste

85 Schulz KF, Chalmers I, Hayes RJ, Altman DG. Empirical evidence of bias. Dimensions of methodological quality associated with estimates of treatment effects in controlled trials. JAMA 1995;273:408-12.

86 Levison ME. Pharmacodynamics of antibacterial drugs. Infect Dis Clin North Am 2000;14:281-91, vii.

87 Hilf M, Yu VL, SharpJ, ZuravleffJJ, Korvick JA, Muder RR. Antibiotic therapy for Pseudomonas aeruginosa bacteraemia: outcome correlations in a prospective study of 200 patients. Am J Med 1989;87:540-6.

88 Chow JW, Fine MJ, Shlaes DM, Quinn JP, Hooper DC, Johnson MP, et al. Enterobacter bacteraemia: clinical features and emergence of antibiotic resistance during therapy. Ann Intern Med 1991;115:585-90.

89 Paul M, Soares-Weiser K, Leibovici L. $\beta$ lactam monotherapy versus $\beta$ lactamaminoglycoside combination therapy for fever with neutropenia: systematic review and meta-analysis. BMJ 2003;326:1111.

90 Kollef MH, Sherman G, Ward S, Fraser VJ. Inadequate antimicrobial treatment of infections: a risk factor for hospital mortality among critically ill patients. Chest 1999;115:462-74
91 Leibovici L, Shraga I, Drucker M, Konigsberger H, Samra Z, Pitlik SD. The benefit of appropriate empirical antibiotic treatment in patients with bloodstream infection. J Intern Med 1998;244:379-86.

92 Bailey JA, Virgo KS, DiPiro JT, Nathens AB, Sawyer RG, Mazuski JE. Aminoglycosides for intra-abdominal infection: equal to the challenge? Surgical Infections 2002;3:315-35.

93 Bodey GP, Middleman E Umsawadi T, Rodriguez V. Infections in cancer patients. Results with gentamicin sulfate therapy. Cancer 1972;29:1697-701.

94 Bayer AS, Bolger AF, Taubert KA, Wilson W, Steckelberg J, Karchmer AW, et al. Diagnosis and management of infective endocarditis and its complications. Circulation 1998;98:2936-48.

95 Paul M, Leibovici L, Grozinsky SG, Silbiger I, Soares-Weiser K. Beta lactam monotherapy versus beta lactam-aminoglycoside combination therapy for treating sepsis (protocol for Cochrane Review). Cochrane Library. Issue 2. Oxford: Update Software, 2003

(Accepted 22 December 2003)

doi $10.1136 /$ bmj.38028.520995.63

Department of Medicine E and Infectious Diseases Unit, Rabin Medical Centre, Beilinson Campus, Petah-Tikva 49100, Israel

Mical Paul consultant

Department of Medicine E, Rabin Medical Centre, Beilinson Campus, Petah-Tikva Ishay Benuri-Silbiger researcher

Karla Soares-Weiser coordinator of clinical research

Leonard Leibovici associate professor

Correspondence to: M Paul mica@zahav.net.il 